\title{
The ecological quality status of the Bay of Seine and the Seine estuary: Use of biotic indices
}

\author{
Jean-Claude Dauvin ${ }^{\mathrm{a}, \mathrm{b},{ }^{*}}$ Thierry Ruellet ${ }^{\mathrm{a}}$, Nicolas Desroy ${ }^{\mathrm{a}, 1}$ and Anne-Laure Janson ${ }^{\mathrm{a}}$ \\ ${ }^{a}$ Station Marine de Wimereux, Université des Sciences et Technologies de Lille, BP 80, 62930 Wimereux, France \\ ${ }^{\mathrm{b}}$ GIP Seine Aval, 12 avenue Aristide Briand, 76000 Rouen, Cedex, France \\ ${ }^{1}$ Present address: Ifremer, LER de Saint-Malo, 2 bis rue Grout Saint Georges, BP 46, 35042 Saint-Malo, France \\ *: Corresponding author : jean-claude.dauvin@univ-lille1.fr
}

\begin{abstract}
:
Using recent indices developed, in part, for use under the European Water Framework Directive (AMBI, BENTIX, BOPA, BQI, I2EC and the trophic index ITI), the ecological quality status of two highly contaminated environments - the Bay of Seine and the Seine estuary (Eastern English Channel)-was determined on several spatial and temporal scales. Data from 604 observations gathered over a 14year period (1988-2002) were analyzed, and the results used to show the relationship between biotic indices, environmental variables and classic descriptors (e.g., number of species, total abundance, dominance index, ES(50) and Shannon/Brillouin diversities). Though the specific ecological quality (EcoQ) values calculated with the various indices were different, the overall trend of the results was similar. Synthesizing the values produced by the six indices used in the study allowed attribution of a high to good EcoQ status to the Bay of Seine and a moderate EcoQ to the estuary. The mesh size used when processing samples was proved to have no effect in winter on the EcoQ values for either body of water.
\end{abstract}

Keywords: Seine estuary; Bay of Seine; English channel; Macrobenthos; Biotic index; Benthic index 


\title{
The ecological quality status of the Bay of Seine and the Seine estuary: use of biotic indices
}

\author{
Jean-Claude Dauvin ${ }^{1,2} *$, Thierry Ruellet ${ }^{1}$, Nicolas Desroy ${ }^{1,3}$, Anne-Laure Janson ${ }^{1}$
}

\author{
${ }^{1}$ Station Marine de Wimereux, Université des Sciences et Technologies de Lille, BP 80, \\ 62930 Wimereux, France and ${ }^{2}$ GIP Seine Aval, 12 avenue Aristide Briand, 76000 Rouen, \\ Cedex \\ ${ }^{3}$ Present address: Ifremer, LER de Saint-Malo, 2 bis rue Grout Saint Georges, BP 46, 35042 \\ Saint-Malo, France \\ * Corresponding author, E-mail address: jean-claude.dauvin@univ-lille1.fr
}

\begin{abstract}
Using recent indices developed, in part, for use under the European Water Framework Directive (AMBI, BENTIX, BOPA, BQI, I2EC and the trophic index ITI), the ecological quality status of two highly contaminated environments- the Bay of Seine and the Seine estuary (Eastern English Channel)—was determined on several spatial and temporal scales. Data from 604 observations gathered over a 14-year period (1988-2002) were analyzed, and the results used to show the relationship between biotic indices, environmental variables and classic descriptors (e.g. number of species, total abundance, dominance index, $\operatorname{ES}(50)$ and Shannon/Brillouin diversities). Though the specific EcoQ (Ecological Quality) values calculated with the various indices were different, the overall trend of the results was similar. Synthesizing the values produced by the six indices used in the study allowed attribution of a high to good EcoQ status to the Bay of Seine and a moderate EcoQ to the estuary. The mesh size used when processing samples was proved to have no effect in winter on the EcoQ values for either body of water.
\end{abstract}

Keywords: Seine estuary; Bay of Seine; English Channel; Macrobenthos; Biotic Index; Benthic Index 


\section{Introduction}

Benthic invertebrates are frequently used as bio-indicators for marine monitoring because they respond rapidly to anthropogenic and natural stress (Pearson and Rosenberg, 1978; Dauvin, 1993; Dauer et al., 2000; Bustos-Baez and Frid, 2003). Macrobenthic organisms are good indicators because they (i) are relatively sedentary and so unable to avoid deteriorating water/sediment quality, (ii) have relatively long life-spans, (iii) include diverse species with different tolerances to stress, and (iv) play a vital role in cycling nutrients and materials between the underlying sediment and the overlying water column. Several authors have reviewed the use of biotic indices (e.g., Diaz et al., 2003 and Occhipinti Ambrogi \& Forni, 2004). Some of these authors accept that a biotic index is unlikely to be universally applicable, because all organisms are not equally sensitive to all types of anthropogenic disturbances and thus are likely to respond differently to different types of perturbations. Several of the indices proposed for evaluating estuarine and coastal water quality have already been used as proxies for detecting the impact of pollution on the macrobenthic communities (see Grall and Glémarec, 1997; Eaton, 2001; Borja et al., 2000, 2003a, 2004a). Given this context, macrobenthic organisms may provide the foundations for a multimetric bioassessment method that can be adjusted for application in different geographical regions (Weisberg et al., 1997; Borja et al., 2000, 2003q, 2004a, b).

In order to implement the European Water Framework Directive (WFD), a series of common concepts, terminologies and tools had to be developed. The process of development has led to a certain degree of controversy within the European scientific community, particularly as concerns the advantages of using the AMBI (AZTI Marine Biotic Index) developed by Borja et al. (2000) as compared to the BENTIX created by Simboura and Zenetos (2002), with some researchers feeling that the AMBI is more appropriate for assessing the EcoQ of transitional (estuarine) and coastal water bodies (see Borja et al., 2004 a, b; Simboura, 2004; Borja and Heinrich, 2005; Muxika et al., 2005). Both indices attribute five environmental status ratings—high, good, moderate, poor and bad-according to the quality of the biological, hydro-morphological and physico-chemical elements present in an area, with the biological elements, especially the benthos, being particularly important. This already complex situation has been further complicated by the development of a new method, the benthic quality index (BQI), for determining marine benthic quality under the European Water Framework Directive (Rosenberg et al., 2004). 
Clearly, the notion of indicators and indices has undergone considerable scientific development in a variety of domains. Many policy and management authorities interested in evaluating the quality of marine systems have endorsed indicator-based approaches to management (Link, 2005). The field of fishery management has provided a suite of indicators (Rice and Rochet, 2005), and is now working to develop ecological indicators able to detect the effect of fishing activities on the environment (Fulton et al., 2005). In short, the implementation of the WFD has provided a marvellous opportunity for those working on the benthos to gauge the efficiency of the numerous bio-indicators and biotic indices-existing and under development-for testing the quality of estuarine and marine environments (see Bricker et al., 2003; Salas et al., 2004; Marin-Guirao et al., 2005; Rogers and Greenaway, 2005).

In the study presented in this article, a variety of biotic indices were applied to data from both the Bay of Seine and the Seine estuary in order to test the pertinence of these indices for highly contaminated environments. The Seine estuary is the largest megatidal estuary in the English Channel, covering approximately $150 \mathrm{~km} 2$ at high tide. Although the water column can be stratified at the mouth of the estuary (ebb and low tide), the estuary is generally well mixed when the discharge of freshwater exceeds $500 \mathrm{~m}^{-}{ }^{3} . \mathrm{s}^{-}{ }^{1}$ (Mouny et al., 1998). The freshwater discharge into the estuary (mean 1975-2005: $484 \mathrm{m3} . \mathrm{s}-1$; N. Bacq personal communication) comes mainly from Seine River and varies seasonally from a maximum of $2200 \mathrm{~m} 3 . \mathrm{s}-1$ in winter to a minimum of $50-100 \mathrm{~m} 3 . \mathrm{s}-1$ in summer. The mean annual particulate river discharge has been evaluated at $650000 \mathrm{t}$ of suspended matter (Avoine, 1994), and the maximum turbidity zone, located at the mouth of the estuary, can sometimes be expulsed into the Bay of Seine during swelling (Lafite and Romana, 2001).

In addition to the disturbances resulting from man-made modifications of the estuary (Dauvin and Desroy, 2005), high levels of heavy metals, particularly cadmium and lead, make the Seine estuary one of the most contaminated in Europe. While the cadmium levels mainly affect benthic and suprabenthic species (e.g., bivalves), elevated levels of zinc have been measured in all species living in the Seine estuary-from benthic invertebrates to fish (Miramand et al., 2001). Addes to these metal contaminants, the level of organic contaminants (e.g., PAHs, PCBs and pesticides) helps to place the Seine estuary among the most contaminated of estuaries (Tronczynski, 1999). The chronic, high-level organic contamination in the Seine estuary is a major concern since the contamination of organisms and ecological resources increases with the trophic level, from benthic and suprabenthic prey to carnivorous fish (Dauvin, in press). Due to the contamination mentioned above and the rapid silting up of 
the estuary (Lesourd, 2001), which will probably increase in response to the Le Havre harbor extension (Dauvin et al., 2006), the environment of the benthic communities existing in the Seine estuary and in the eastern part of the Bay of Seine can be said to be perturbed.

Given the concentration of environmental disturbances, the different areas in the Bay of Seine have been studied more or less intensively at a variety of spatial scales (Thiébaut et al., 1997; Dauvin et al., 2004). A large-scale project assessing the effect of previous dredging on the benthic communities throughout the bay was carried out in 1997 (Gentil and Cabioch, 1997), and in 2002 the first mesoscale quan titative study of the bay was conducted (Ghertsos, 2002). Beginning at the end of the 1990s, several other benthic studies were conducted at different spatial and temporal scales, of ten with the support of the Seine-Aval scientific program. Recently, a new database called MABES (Macrobenthos of the Bay and Estuary of Seine; available via the data administrator of the GIP Seine Aval: nbacq @seine-aval.fr) was set up to collect the benthic data from the Bay of Seine and the Seine estuary.

The data examined in this paper come from the MABES database. Through this examination, we seek (i) to evaluate the usefulness of the recent benthic biotic indices proposed for implementing the WFD, (ii) to compare their pertinence in terms of the existing indices, and (iii) based on the results produced by the various indices, to identify the response of the macrobenthic communities in the Bay of Seine and the Seine estuary to a highly contaminated environment.

\section{Material and methods}

\subsection{The Bay of Seine}

The Bay of Seine forms a roughly $5000-\mathrm{km}^{2}$ quadrilateral measuring $\cong 50 \mathrm{~km}$ from north to south and $\cong 100 \mathrm{~km}$ from west to east, with mostly regular morphological features (Fig. 1). Opening wide onto the central English Channel in the north, the Bay of Seine never exceeds $30 \mathrm{~m}$ in depth. To the north of the Pays de Caux and northwest towards the Cotentin Strait, the maximum speed of the tidal currents is 3 knots. In the eastern part of the Bay, the current is weak-less than 1.5 knots on the surface (average spring tide). These tidal currents, added to the general drift of the water, play an essential role in distributing both sediment and benthic communities, as well as in dispersing river input, especially from the Seine River (Gentil and Cabioch, 1997). Together, they create an offshore-inshore gradient in the Bay, with the dominant sediment offshore generally consisting of pebbles, gravel and coarse sand, 
and the sediment inshore in the coastal zones-especially in the western part of the Bay (Bay of Veys) and in the eastern part just in front of the Seine estuary-consisting mostly of fine sand, and silty/muddy fine sands.

In the Bay of Seine, Gentil and Cabioch (1997) identified six main macroben thic communities: (i) an pebble-inhabiting community offshore in which strong tidal currents prevail; (ii) a coarse-sand to sandy-coarse-gravel community, with dense patches of the ophiurid Ophiothrix fragilis, occupying the central part of the bay; (iii) a medium-to-fine sand Ophelia borealis community linked to hydrodynamic sand dunes; (iv) a muddy-fine sand Abra alba-Pectinaria koreni community; (v) a heterogeneous muddy community, and (vi) a muddy Macoma balthica community in the estuary and the inner part of the Bay of Veys (Fig. 1), the last four populating the eastern and western parts of the Bay.

\subsection{Macrobenthic sampling}

Table 1 summarizes the main characteristics of the quantitative samples taken from the subtidal macrobenthic communities in the Bay of Seine at four spatial scales.

(i) The entire Bay of Seine. A total of 90 sites were sampled-44 in September 1998 and 46 in May 1999 - over a wide grid measuring approximately $100 \mathrm{~km}$ (East to West) by 50 km (North to South, Fig. 1), which encompasses the entire Bay of Seine (Ghertsos, 2002). The distance between sampling sites was about 5 nautical miles. Although two biological samples provide more than the required precision (i.e. 5\%) for estimating the densities of the main populations (Thiébaut et al., 1997), four replicates were collected at each site using a Hamon grab $\left(0.25 \mathrm{~m}^{2}-10 \mathrm{~cm}\right.$ depth, Eleftheriou and Holme, 1984). This grab, judged best suited to the varying sedimentary environments, was chosen to avoid the inevitable problems of incomparability had different grabs been used in different areas. An additional $5^{\text {th }}$ sample was collected at each of the sites in order to analyze such environmental parameters as granulometry, total organic matter and pigment (chlorophyll $a$ / phaeopigments, Ghertsos, 2002).

(ii) The Bay of Veys. The macrofaunal distribution in the Bay of Veys was determined by two surveys conducted in 1997 (Fig. 1, Dauvin et al., 2004). The first was performed in March (55 sites) before the recruitment period of the dominant species, and the second, in October (54 sites), following the main recruitment period. The distance between sampling sites was about 1 nautical mile. Most of the sites were located in the muddy/fine-sand Abra alba-Pectinaria koreni community, though the sampling grid was completed by few off shore 
sites located in the fine-sand Ophelia borealis community (Gentil and Cabioch, 1997). All benthic sampling was carried out using a Hamon grab, with two grabs collected at each site for biological analysis and one for sediment characterisation.

(iii) The Eastern part of the Bay of Seine. The macrofauna distribution in the eastern part of the Bay of Seine was established from three benthic surveys organized before the recruitment period of the dominant species_-in February 1988, March 1991 and March 1996 (Thiébaut et al., 1997; unpublished data). Grids of 64, 64 and 77 sites, respectively, were sampled during each survey (Fig. 1 and 2). The distance between sites was about 1.5 nautical miles. Most of the sites were located in the muddy/fine-sand Abra alba-Pectinaria koreni community and its heterogeneous muddy/sand facies, as well as in the medium-sand Ophelia borealis community. Samples were collected using a Hamon grab, with three grab samples being collected at each site, two for biological an alysis and one for granulometric analysis.

(iv) The Seine Estuary. Four different surveys were carried out in the estuary, each at a different spatial and temporal scale.

- Three replicate samples were taken in November 1993 using a $0.1 \mathrm{~m}^{-2}$ SmithMcIntyre grab at two sites located in the Navigational Channel of the Seine estuary, downstream from Honfleur. Later, three sites were sampled in May and October 1995 in the upper part of the Navigational Channel (Honfleur-Pont de Tancarville), using a Rallier du Baty dredge (samples containing about 30 L of sediment) (Mouny et al., 1998);

- Eleven sites situated in the Northern Channel of the estuary were sampled in February 2001 using a Hamon grab, the distance between sites being about 1 nautical mile. Four grab samples were collected at each site for biological analysis, plus an additional sample for sediment characterisation.

- A total of 23 sites were sampled in March, May and September 2002 using a Hamon grab (two samples for biological analysis and one for sediment characterisation). These sites were located throughout the polyhaline zone of the estuary, the North and South Channels, and the mouth of the estuary (Janson and Desroy - unpublished data, Fig. 3).

- Four sites-one in the North Channel, one in the South Channel and two at the mouth of the estuary-were sampled regularly with a Van Veen grab from March to December 2002 (10 dates for all sites, except the North Channel site, which was sampled only 9 times) (Janson and Desroy - unpublished data). The benthic assemblages studied were the muddy/fine-sand Abra alba - Pectinaria koreni 
community that occupy the external part of the estuary and the entrance to the North and South Channels, and the Macoma balthica community that is spread throughout the inner subtidal bottoms in the North, South and Navigational Channels (Dauvin and Desroy, 2005).

In the above studies cited, the samples collected with the Hamon grab were sieved through a $2 \mathrm{~mm}$ mesh, except for those taken in February 2001, which were processed using both $2 \mathrm{~mm}$ and $1 \mathrm{~mm}$ mesh sizes. For samples collected with other gear (the Smith McIntyre or Van Veen grabs and the Rallier du Baty dredge), a circular 1mm-mesh sieve was preferred. For all the samples in all surveys, the biological material retained by the sieve meshes $(1 \mathrm{~mm}$ or $2 \mathrm{~mm}$, see table 1 for details) was fixed in $4 \%$ buffered formaldehyde mixed with seawater until it could be sorted, identified to the species level, and counted in the laboratory. Abundances were expressed in nb ind $0.5 \mathrm{~m}^{-2}$.

Table 1 shows the number of sites for which environmental parameters were measured and are available. The size distribution of sediment particles was analysed by wet sieving; the results in Table 1 are expressed in percentages for the five sediment grain sizes: gravel (> 2 $\mathrm{mm}$, denoted G), coarse sand $(500 \mu \mathrm{m}-2 \mathrm{~mm}$, denoted CS), medium sand (200-500 $\mu \mathrm{m}$, denoted MS), fine sand (63-200 $\mu \mathrm{m}$, denoted FS), and silt/clay ( $63 \mu \mathrm{m}$, denoted silt). The total organic matter rate was measured using a method of weight loss upon ignition. Using spectrophotometry, the level of chlorophylls $a, b$ and $c$, as well as of phaeopigment values and carotenoids, was measured after dilution in acetone (results in $\mu \mathrm{g} / \mathrm{cm}^{3}$ of sediment) (Ghertsos, 2002).

All results were compiled in a database comprising 604 observations and 392 species.

\subsection{Biotic indices}

Numerous biotic indices have been proposed in the literature (see Gomez Gesteira and Dauvin, 2000; Diaz et al., 2003; Occhipinti Ambrogi and Forni, 2004; SGSOBS, 2004). Among the indices available, we chose to evaluate six (Table 2): the Infaunal Trophic Index (ITI) (Mearns and Word, 1982) based on trophic groups; the indices AMBI (Borja et al, 2000), BENTIX (Simboura and Zenetos, 2002), I2EC (Grall and Glémarec, 2003) and BOPA*

\footnotetext{
* The BOPA index is an improved version of the Opportunistic Polychaetes/Amphipods ratio proposed by Gomez Gesteira \& Dauvin (2000). It takes into account the total number of individuals collected, the frequency of opportunistic polychaetes, and the frequency of amphipods, except the genus Jassa (Dauvin and Ruellet, submitted).
} 
(Gomez Gesteira and Dauvin, 2000; Dauvin and Ruellet, submitted), all based on ecological groups; and the Benthic Quality Index (BQI) (Rosenberg et al., 2004), developed specifically for use under the WFD. Other quantitative variables were also considered [e.g., number of species $(\mathrm{S})$, number of individuals $(\mathrm{N})$ ), as were several univariate indices (e.g., dominance index, H' Shannon diversity index, H Brillouin diversity index] (Table 2). In addition, the expected number of species present for 50 individuals was also calculated (Primer version 5) to allow the BQI (Rosenberg et al., 2004) to be established (Table 2).

The ITI was determined in consideration of the feeding habits of macrobenthic species, as specified by Thiébaut et al. (1997) and Ghertsos (2002). The four main trophic groups (TG) retained were those defined by Mearns and Word (1982): (TG1) suspension feeders, (TG2) carrion feeders (e.g. carnivorous, omnivorous and necrophagous), (TG3) surface deposit feeders and those species that are both suspension feeders and surface deposit feeders, and (TG4) subsurface deposit feeders that feed on sedimentary detritus and bacteria.

The indices based on ecological groups all refer to the same five ecological groups. These groups are ranked according to their sensitivity to an increasing stress gradient as per the regularly updated list published by the AZTI Laboratory (www.azti.es): Group I (species very sensitive to organic enrichment), Group II (species indifferent to enrichment), Group III (species tolerant of excessive organic enrichment), Group IV (second-order opportunistic species) and Group V (first-order opportunistic species). Less than $8 \%$ of the taxa observed in the Bay of Seine and the Seine estuary could not be assigned to an ecological group. The AMBI was calculated following the guidelines of Borja and Muxika (2005).

To use the BQI, it was first necessary to calculate the expected number of species present in 50 individuals (Table 2). This $\operatorname{ES}(50)_{0.05}$ was calculated for 90 of the 392 taxa, using the thresholds proposed by Rosenberg et al. (2004) for species present at least in 20 observations where the total abundance is higher than 50 individuals.

\subsection{Data analyses}

Since the database encompasses different spatial and temporal scales, several patterns were considered for the distribution of biotic indices in the Bay of Seine.

(i) Large spatial scales were available for two periods: 1) prior to the recruitment period of the principle benthic species (see Thiébaut et al., 1997; Dauvin et al., 2004)—based on 176 observations from the March 1996, March 1997 and May 1999 surveys, and 2) 
following the recruitment period-based on 98 observations from the September 1998 and October 1997 surveys;

(ii) Inter-annual temporal changes were detected in the eastern part of the Bay of Seine based on 203 observations from 3 surveys: February 1988, March 1991 and March 1996;

(iii) The influence of the salinity gradient was observed from the polyhaline to the oligohaline zones based on 8 observations at 5 sampling sites in the Navigational Channel.

(iv) Seasonal changes were detected in the estuary based on 69 observations from surveys conducted at 23 sites in March, May and September 2002 and on 39 observations from 3 sites sampled 10 times and 1site sampled 9 times in a single year;

(v) The effect of mesh size ( $1 \mathrm{~mm}$ vs $2 \mathrm{~mm}$ ) was evaluated based on 44 observations from 11 sites in the Seine estuary sampled in February 2001.

Only a selection of some indices was shown for each scale, but in the discussion all the indices were integrated to establish the EcoQ status of the studied area (see Fig. 7 for the range of the 12 variables).

\subsection{Statistical analysis}

The relationships between number of species and abundance versus sediment parameters and biotic indices were tested using Spearman's rank correlation coefficients (Scherrer, 1984) with XLSTAT-Pro version 5.1.4 (ㄷ Addinsoft).

\section{Results}

\subsection{Large spatial scales}

For both sampling periods, AMBI produced very low values, indicating a high or good ecological status for the whole Bay of Seine, independent of the recruitment phenomenon (Fig. 4). Still, the general status does appear to be slightly better in autumn than in spring. Since no values attained the threshold of 3.3 (corresponding to moderate status), no gradient could be identified. Zones with values ranging between 1.2 and 2.3 (good status) were located both near the Seine estuary and offshore prior to the recruitment period, and near the Bay of Veys after the recruitment period.

On the other hand, according to the BQI, the situation was both worse and more contrasted for both seasons, with status values varying from good to poor. Despite these 
unpromising ratings, the general EcoQ status in the Bay of Seine improved between the two periods. Prior to the recruitment period, several poor status zones were identified just in front the Seine estuary and offshore in the northern and western parts of the bay; moderate status zones were found throughout the central section of the Bay, with good status zones appearing along the southern coast. After the recruitment period, the EcoQ for the shallow waters of the bay was generally good, except locally near the Seine estuary. Only one site, located in the northwestern part of the bay could be ranked as poor, while the rest of the northwestern section attained moderate status.

\subsection{Inter-annual temporal changes in the eastern part of the Bay of Seine}

During the three-winter/spring periods, the general status indicated by the AMBI index was high or good (Fig. 5). However, AMBI also underlined an improvement in the water quality over time, with the majority of the sites that attained good status in 1988 and 1991 evolving toward high status by 1996. Although the Bay of Seine obtained a worse rating from the BQI for the same three years, with a gradient ranging from poor in front of the Seine estuary to good in the offshore bottoms, the overall trend with the BQI was also towards improved water quality over time (Fig. 5).

\subsection{Effects of the salinity gradient}

Based on data collected in 1993 and 1995 (not presented in this study), the EcoQ status of the Seine estuary as defined by the AMBI ranged from good to high, while the status calculated with the BQI ranged from bad to good (Fig. 5). The ITI classified the Seine estuary and the Bay of Veys as modified zones $(30<\mathrm{ITI}<60$, data not shown), according to the definitions proposed by Bascom et al. (1978). This classification can be explained by the presence of a small degraded zone $(\mathrm{ITI}<30)$ in the middle of the channel between Honfleur and Le Havre and a larger such zone in the Bay of Veys. The ITI classification for the other sections of the Bay of Seine was predominantly normal or slightly modified.

\subsection{Annual temporal changes in the estuary}

Surveys of 23 sites located in the Seine estuary done in March, May, and September 2002 indicate small seasonal changes. Using the AMBI index produced a predominance of 
good status ratings, while using the BQI resulted in an inshore-offshore gradient ranging from poor to good status, with an occasional bad status rating (Fig. 6).

\subsection{Relationship between demographics, sediment parameters and the biotic indices}

Figure 7 presents the range of variations and the median value of each index for the 11 datasets tested. Although each of the 12 indices produced a range of widely varying values, calculating the median values allows some general trends to be highlighted. Overall, the S, N, $\mathrm{H}^{\prime}$ and Brillouin diversity values were higher in the Bay of Seine than in the Seine estuary, reflecting the more diverse communities of the Bay of Seine (Fig. 1). Nevertheless, due to presence of numerous polychaetes in samples, the 2002 survey of four sites in the Seine estuary (9 or 10 sampling dates) indicated high abundance values at the end of spring and at the beginning of autumn at the same sites (data not shown).

Figure 8 presents the results of the Spearman correlations between the environmental variables (e.g., organic matter and pigments in the sediment, percentages of the five grain sizes) and the various indices and descriptors measured. Absolute values are used because the sign of the relationship between two indices has no biological signification; it shows only that these indices used scales that vary in opposite directions. The expected number of species, the actual number of species, the BQI, the Shannon diversity and the dominance index were significantly correlated $\left(0.42 \leq\left|\mathrm{r}_{\mathrm{s}}\right| \leq 0.97, \mathrm{p}<0.01\right)$. Since the classification of the benthic species into ecological groups is taken into account the calculation of all the indices, correlations were also significant $(\mathrm{p}<0.01)$ between the benthic Biotic Indices-AMBI, BENTIX, I2EC and BOPA. Similarly, the BOPA index and BQI, S, ES(50) and H' were also significantly correlated. The correlation between the biotic indices and sedimentary organic matter and pigment content was weak $\left(\left|\mathrm{r}_{\mathrm{s}}\right| \leq 0.28, \mathrm{p}<0.01\right)$, indicating that these variables do not influence the EcoQ status in the Bay of Seine. The ITI was weakly correlated with the other indices $\left(\left|\mathrm{r}_{\mathrm{s}}\right|<0.20\right)$, but was significantly $(\mathrm{p} \leq 0.01)$ correlated with granulometry $\left(\left|\mathrm{r}_{\mathrm{s}}\right|<0.30\right.$ for three fractions of sediment) and slightly correlated with pigment content $\left(r_{s}=-0.24\right)$, though not with the concentration of organic matter in the sediment $(\mathrm{p}=0.12)$. All the biotic indices calculated were significantly correlated $\left(\left|\mathrm{r}_{\mathrm{s}}\right|<0.25 \mathrm{p}<0.05\right)$ with the sedniment grain size, except for medium sand with AMBI $\left(\mathrm{r}_{\mathrm{s}}=-0.30, \mathrm{p}<0.01\right)$.

\subsection{A comparison of AMBI and BQI}


Figure 9 shows the relative frequency of the AMBI and BQI values inside (respectively 419 and 372 values) and outside (respectively 185 and 148 values) the Seine estuary. Curves were computed using classes of 0.25 for AMBI and 2 for BQI and smoothed for a 0.05 step with Table Curve 2D software (C SPSS). The AMBI revealed similar quality status ratings for both areas (inside and outside the estuary), though estuary sites had higher values than those outside of the estuary $($ mode $=1.35$ for inner sites compared to 0.80 for outside sites). The AMBI/BQI comparison revealed the strong divergences within the BQI values, highlighting two distinct areas: the estuary sites, with low values (mode $=2.7$ ), reflecting the bad to poor status of the estuary; and the offshore sites, with high values (mode $=7.6$ ), indicating the moderate to high status that prevails in areas less influenced by the input from the Seine River.

\subsection{The effect of mesh size}

To assess the effects of the mesh size on the EcoQ of the water bodies studied, the values of the six selected indices, calculated for the 11 sites sampled in February 2001, were compared after the biological samples had been sieved through a $2 \mathrm{~mm}$ or a $1 \mathrm{~mm}$ mesh (Fig. 10). After sieving with a $1 \mathrm{~mm}$ mesh, the values for $\mathrm{S}, \mathrm{N}$ or $\mathrm{H}^{\prime}$ increased moderately, except at one site (60) located in the upper part of the estuary. The AMBI, BQI and BOPA also exhibited moderate changes depending on which mesh size was used. Specifically, when a $1 \mathrm{~mm}$ mesh was used instead of a $2 \mathrm{~mm}$ mesh:

- the AMBI revealed a change in status from good to moderate at one site (59);

- the BQI showed that two sites (16 and 57) improved from moderate to good, while two others (17 and 62) degraded from moderate to poor;

- the BOPA indicated a change from moderate to good at site 60 and from good to moderate at site 64 .

Clearly, the size of the mesh used does not influence the value ranges or the medians for the 12 indices (Fig. 7, j and k). For several indices (the $\operatorname{ES}(50)_{0.05}$, the dominance index, the Shannon and Brillouin diversities and the I2EC index), the mesh size made absolu tely no difference. AMBI and BENTIX values span a wider range with the $2 \mathrm{~mm}$ mesh than with the $1 \mathrm{~mm}$ mesh, which was the opposite of the results for the BQI, BOPA and ITI. The median value for I2EC was often equal to the minimum or maximum values because I2EC uses a discontinue scale. The median BOPA value was often near or equal to 0 because the opportun istic polychaetes and the amphipods are lightly represented in the Bay of Seine. 


\section{Discussion}

\subsection{EcoQ status of the Bay of Seine and the Seine estuary}

In general, the results of our study suggest that the indices perform satisfactorily. It is true, however, that the ecological quality status of the Bay of Seine and the Seine estuary appears to be different, depending on which the biotic index was used.

- AMBI produced EcoQs that were generally high in the bay and good in the estuary.

- BENTIX, on the other hand, attributed a high status rating to both the bay and the estuary, except for a couple of sites just offshore of the Seine estuary that had a good to moderate EcoQ.

- The BOPA index assigned a high EcoQ to the bay, while the estuary's status rating ran ged from high to poor, with a predominance of good and moderate ratings.

- The BQI produced values that indicate that all five-status ratings exist in the Bay of Seine and Seine estuary; this finding is consistent with the definition of the EcoQ status ratings proposed by Rosenberg et al. (2004), which supposes that extremes (high and $\mathrm{bad}$ ) exist in each data set (Labrune et al., 2006). Despite this wide distribution, good and moderate EcoQ dominate in the bay, while poor and bad EcoQ exist primarily near the Seine River, providing evidence of the benthic degradation in this part of the Seine estuary.

- The I2EC results are more disparate: high EcoQ were produced for off shore areas, high to good EcoQ for areas near the coast, and poor and bad EcoQ for some estuary sites.

- The ITI values indicate that the Bay of Seine is primarily normal or slightly modified and that the Seine estuary and the Bay of Veys were generally modified but locally degraded.

Despite differences in EcoQ ratings, the overall general trend is similar: offshore areas have better EcoQs (high or good) than the estuarine areas, which are more contaminated. However, the variations between the indexes underline the need to calibrate the thresholds between the classes defined for each index and seasonal variations detected by indices must be integrated for the assessment of the EcoQ classification (Borja, personal communication).

Our results are consistent with those published by Simboura (2004), which show that the EcoQ produced with AMBI and BENTIX do not totally agree and that EcoQ ratings may 
differ when calculated using the classic univariate and multivariate methods in vogue prior to the development of the newer WFD-inspired indices. Thus, the question that needs to be answered appears to be two-fold: what benthic indices are best suited to evaluating contaminated coastal areas and estuaries, and is it best to use a single index, a set of indices, or a multimetric approach?

\subsection{Single index versus multimetric approach}

According to Dale and Beyeler (2001), a useful ecological disturbance indicator is one that is easily calculated, sensitive, anticipatory, and integrative across key environmental gradients. However, although a single index may provide a good overview of the gradient status of a benthic environment, choosing one that will definitively establish the true status of a specific site is difficult. Some of the practical problems related to using a single index include questions about classifying species as indicators for different disturbance levels, sensitivity to dominance, and lack of objectivity when setting stress effect thresholds (Salas et al., 2004). Several studies have underlined the inconsistencies between diversity indices, stemming from the biological characteristics of the area being studied. The AMBI index, for example, sometimes appears to be more appropriate for the Atlantic ecosystems and estuarine areas with low biodiversity, few species and high densities; the BENTIX index, on the other hand, seems better suited to determining EcoQ in Mediterranean coastal ecosystems with high biodiversity (Simboura, 2004).

In addition, sometimes the source of the disturbance must be identified in order to choose the appropriate index. For instance, AMBI, as probably others indices, is not always able to differentiate between the origins of the diverse stresses and thus can produce similar values for differing stress factors (Salas et al., 2004). Added to the difficulties mentioned above, as Marin-Guirao et al. (2005) recently remarked, neither AMBI nor BENTIX - to be fair, probably none of the existing indices-are suitable for monitoring all the purely toxic pollutions. In response to this shortcoming, these authors have suggested developing a new indicator list, with each indicator adapted to a specific type of contamination (e.g., metals, pesticides, hydrocarbons). For all of these reasons, though it is always possible to choose a single index that, like AMBI, has been tested in a variety of situations (Muniz et al., 2005), it seems preferable to combine several indices when assessing the EcoQ status of an area in order to take the complexity of the ecosystem into consideration and to minimize errors (Dale 
and Beyeler, 2001; Alden III et al., 2002; Borja et al., 2003a; Borja and Muxika, 2005; Muniz et al., 2005; Rogers and Greenaway, 2005).

Dale and Beyeler (2001) echo Dauer et al. (1993) when they suggest the complementary use of an appropriate succession of indices, matched to the characteristics of the environment in question, for determining the environmental quality of ecological systems. However, in order to properly evaluate this suggestion, the practical limits of the various indices must be acknowledged.

As in all indices, and despite its excellent properties, AMBI clearly appears to have certain limitations, though their extent is not yet apparent. For example, unsatisfactory results have been obtained using AMBI in situations with low abundance and/or low specific richness values (Muniz et al., 2005). Regardless, Simboura (2004) recommends using AMBI rather than BENTIX in sites where specific richness is low and total abundance is high, considering that AMBI more exactly defines the ecological groups of the sampled species (five groups for AMBI versus only two for BENTIX). This said, Simboura (2004) also feels that, in some situations, AMBI is less discriminating than BENTIX and the older methods. Since the percentage of taxa not assigned to an ecological group is an important factor in correct AMBI use (for that matter, in the use of BENTIX and I2EC also), AMBI's own creator recommends choosing an index other than AMBI when this rate exceeds $20 \%$ (Borja and Muxika, 2005). In our data set, this threshold was not reached since only $7.65 \%$ of the taxa were not assigned to an ecological group.

Based on a different approach of ecological grouping, the BQI remains a highly empirical index, which requires the analysis of individual data sets. This index, which is highly sensitive to dominance and has a tendency to classify dominant species as tolerant (Labrune et al., 2006), requires samples with a minimum abundance of 20 individuals (Rosenberg et al., 2004) and a large data set in order to improve the accuracy of the ES(50) 0.05 used to calculate the BQI. Thus, habitats falling short of such requirements should be evaluated with another index. Others alternatives include the ITI, the B-IBI (Benthic-Index of Biotic Integrity; Llanso et al., 2002a, b) or the BOPA index; however, using these last three indexes optimally also requires meeting certain environmental specifications. For example, the ITI works better at depths under 20 m (Donath-Hernandez and Loya-Salinas, 1989), and so another index would be more appropriate for higher depths. Similarly, since Llanso et al. (2002b) exclude amphipods from the calculation of the B-IBI in the oligohaline areas, using the BOPA index would appear judicious in areas with salinity levels greater than 5 . Since managers require indicators that vary only slightly over the seasons and/or years, using such 
benthic indices can be problematic because they vary seasonally and depend on the different environmental conditions for the various marine regions, as Reiss and Kröncke (2005) have underlined.

Taking the known limitations of each index in to account would make it possible to choose one index for the off shore areas, and another one for coastal and transitional waters. Such a process would not be a problem in terms of WFD application as long as the final results are expressed as ratios (comparison to a state of reference) ranging from 0 to 1 . Unfortunately, for the moment, such states of reference remain undefined at the European level due to insufficient spatio-temporal data. However, they already exist for Basque Country in Spain (Borja et al., 2004b) and for Denmark, Norway and UK (Borja, personal communication).

In order to fulfil the WFD requirements for water quality assessment, Vincent et al. (2002) thought that methods combining composition, abund ance and sensitivity might be the most promising. If their reasoning is accepted, the knowledge of the indices' limitations could be applied to develop a multimetric approach. The B-IBI-which takes into account, in a single cumulative value, several indices $\left(\mathrm{H}^{\prime}, \mathrm{N}\right.$, percentage of sensitive and opportunistic species, percentage of $\mathrm{TG}_{2}$ and $\mathrm{TG}_{4}$, and others metrics, including biomass) — is one example of such a combinatory approach (Llanso and Dauer, 2002; Llanso et al., 2002b; Dauer and Llanso, 2003). The EQR (Ecological Quality Ratio) (Borja et al., 2003b)—which combines the Shannon-Wiener Index, the species richness and the AMBI in one cumulative index-is another, although Reiss and Kroncke (2005) have already shown in their study of different areas in the North Sea (the German Bight, the Oyster Ground and the Dogger Bank) that the ecological status rating produced by this EQR is generally one or two categories below the other indices and consequently recommended to use a multivariate analysis to determine a best EQR (see Borja et al., 2004b).

To determine EcoQ status ratings under the WFD, we propose that the results produced by each index be scored from 1 ( high) to 5 ( $b a d)$, with all scores being averaged to determine the definitive ecological quality of an area. This proposition is consistent with the recommendations of Dauer et al. (1993) and Salas et al. (2004), who advise using a variety of indices based on different approaches. That differs to the possibility offer by the WFD to use different metrics and methods following the Member States and then to intercalibrate the metrics (Borja et al., 2004 b). The relationships between the indices calculated with our data set suggest that three parameters should be taken into account: species diversity, the proportions of the various ecological groups, and trophic structure. Since the indices based on 
the first two were highly correlated, it would seem sensible to use at least one index for each parameter. Using this approach, the Bay of Seine earns a high to good EcoQ, while the estuary garners a moderate EcoQ.

\subsection{Relationship between the indices and the environmental variables}

Our results show that the Seine estuary and the Bay of Veys (at least, according to certain indices) are more degraded than the Bay of Seine, probably due to the severity of the disturbances that prevail in estuarine areas. Still, these results must be interpreted with prudence because the classification method is less efficient in low salinity areas, including both tidal freshwater and polyhaline areas (Llanso et al., 2002b). Benthic indices often have trouble differentiating between the effects of salinity and the effects of pollution due to river discharge (Alden III et al., 2002). The AMBI and BQI indices, for example, have different discriminating capacities, depending on whether the site is estuarine or non-estuarine (Fig. 9). If this difference is due to a pollution gradient, then the BQI would appear better suited to detecting anthropogenic responses than AMBI. If not, it would mean that the BQI is more sensitive to the salinity gradient than is AMBI.

Clearly, salinity has a strong influence on the index values. Thus, in order to compare the results obtained, ecological assessments of estuarine habitats—which are often irregular, silted-up, and rich in organic matter-can best be accomplished using data detrending methods (Dauer et al., 2002). However, salinity is not the only influencing factor. Sediment type, as well as salinity, defines benthic habitats and their faunistic assemblages, and the qualitative and quantitative compositions of these benthic habitats modulate the values of benthic indices (Llanso et al., 2002a). In addition, Maurer et al. (1999) have shown that granulometry can affect the infaunal trophic index. This proved true in the Bay of Seine and the Seine estuary, where the ITI values increased as the proportion of suspension feeders increased, in relation to increases in offshore coarse sediment.

According to our results, the organic matter content in the sediment did not play a determining role in the ecological status of the Bay of Seine and the Seine estuary, nor did the structure of the benthic fauna (Thiébaut et al., 1997). Though this is not the first time that no correlation has been found between organic matter content in the sediment and biotic indices (see Muxika et al., 2005 for AMBI), it seems clear that indices based on ecological groups (e.g., AMBI, BENTIX and I2EC) are rooted in a model that predicts a succession of species along an organic matter gradient (Borja et al., 2000). This model does not correspond with our 
observations may be because indices values were used instead of ratios due to the absence of reference conditions, as underlined previously, and because the estuarine and coastal environments of the Seine have been largely modified by human activities for many decades. Despite a general disturbance, a benthic community can be considered in good status in the frame of the WFD (Borja et al., in press).

Presumably, the benthic communities in the Bay of Seine and the Seine estuary have adapted progressively to the high organic content in the sediment of a megatidal area with high tidal currents. The eastern part of the Bay of Seine and the Seine estuary exhibit widely contrasting features, with some areas displaying abundance and biomass values that are among the highest for all European and North American estuaries, and other areas that are quite impoverished (Dauvin, in press). The subtidal macrobenthic community near the Seine estuary presents a paradox: despite the relatively low numbers of opportunistic species, such as polychaetes, and despite being located in a zone with high levels of dissolved contaminants, very high abundance and biomass values have been recorded. This paradox might be due to the delay in this area between the periods with the maximum runoff and the maximum contaminant input (at the end of autumn and during the winter) and the period of recruitment for the principle abundant species (throughout the spring and summer) (Thiébaut et al., 1997). The absence of anoxic conditions, especially in the summer when temperatures reach their maximum $\left(>20^{\circ} \mathrm{C}\right)$, might also explain the high abundance and biomass values found in the Seine estuary, despite the highly contaminated environment (Dauvin, in press). Nevertheless, it should be noted that, probably in response to the contamination of the environment, the number of species sensitive to pollution (e.g., amphipods) is relatively low in the entire Bay of Seine and Seine estuary (Dauvin and Ruellet, submitted).

In their work on the Chesapeake Bay, Dauer and Llanso (2003) have suggested that studying the effect of decreases in oxygen content requires sampling on a smaller spatial scale than does studying overall contamination in sediment. In light of the relationship between the indices and environmental variables, it would seem that the scale of observation must be adapted to the type of natural and anthropogenic perturbations.

\subsection{Future researches}

A long-term global observation strategy is needed for the Bay of Seine and the Seine estuary. The mesh size used has few effects on the EcoQ classification in our results $(2 \mathrm{~mm}$ vs. $1 \mathrm{~mm}$ ). Nevertheless our comparison takes into account only winter samples, a period 
outside the recruitment of the main benthic species of the Bay of Seine (Ghertsos, 2002). A smaller mesh $(0.5 \mathrm{~mm})$ could give other results because opportunistic species have oftensmaller size than sensitive species. Thus, it is necessary to take into account special attention on this point for the future. As part of the WFD coastal zone implementation, an inshore/offshore transect should be chosen for observation and a variety of benthic indices selected for use in periodic assessments. In addition, an integrated ecosystem approach similar to the one adopted by the Bergen Declaration for managing human activities in the North Sea (http://odin.dep.no/archive/mdvedlegg/01/11/Enge1069.pdf, Carlberg, 2005) should be applied in the offshore zone of the defined transect.

\section{Acknowledgements}

This study was undertaken as part of the Seine-Aval program, which is coordinated by the Haute Normandie region and the French National Coastal Environment Program (PNEC 'Chantier Baie de Seine'). It was supported financially by the CNRS-INSU and IFREMER. The authors are grateful to the crews of N.O. 'Côte d'Aquitaine' and N.O. 'Côtes de la Manche' for their help during sampling; to the co-organizers of the sampling surveys-L. Cabioch, F. Gentil, K. Ghertsos, M. Ropert, and C. Retière; to the numerous students who participated in the surveys and in the development and use of the benthic sampling data, to A. Borja for his comments on the first version of this paper, and to L. E. Spencer for her comments and help in correcting the English text.

\section{References}

Alden III, R.W., Dauer, D.M., Ranasinghe, J.A., Scott, L.C., Llanso, R.J., 2002. Statistical verification of the Cheasapeake Bay benthic index of biotic integrity. Environmetrics 13, 473-498.

Avoine, J., 1994. Synthèse des connaissances sur l'estuaire de la Seine. Sédimentologie. Rapport IFREMER-Port Autonome du Havre, 154 p.

Bascom, W., Mearns, A.J., Word, J.Q., 1978. Establishing boundaries between normal, changed and degraded areas. California Coastal Water Research Project, Annual Report 1978, 81-94. 
Borja, A., Franco, J., Perez ,V., 2000. A marine biotic index to the establish ecology quality of soft-bottom benthos within european estuarine coastal environments. Marine Pollution Bulletin 40, 1100-1114.

Borja, A., Muxika, I, Franco, J., 2003a. The application of a marine biotic index to different impact sources affecting soft-bottom benthic communities along the European coasts. Marine Pollution Bulletin 46, 835-845.

Borja, A., Franco, J., Muxika, I., 2003b. Classification tools for marine ecological quality assessment: the usefullness of macrobenthic communities in an area affected by a submarine outfall. ICES CM 2003/Session J-02, Tallinn (Estonia), 24-28 September 2003.

Borja, A., Franco, J., Muxika, I., 2004a. The Biotic Indices and the Water Framework Directive: the required consensus in the new benthic monitoring tools. Marine Pollution Bulletin 48, 405-408.

Borja, A., Franco, J., Valencia, V., Bald, J., Muxika, I., Belzune, M.J., Solaun, O., 2004b. Implementation of the European water framework directive from the Basque country (northern Spain): a methodological approach. Marine Pollution Bulletin 48, 209-218.

Borja, A., Heinrich, H., 2005. Implementing the European Water Framework Directive: the debate continues... Marine Pollution Bulletin 50, 486-488.

Borja, A., Muxika, I., 2005. Guidelines for the use of AMBI (AZTI's Marine Biotic Index) in the assessment of the benthic ecological quality. Marine Pollution Bulletin 50, 787-789.

Borja, A., Muxika, I., Franco, J., in press. Long-term (1989-2003) soft-bottom benthos recovery following urban and industrial sewage treatment in the Nervión estuary (Basque Country, northern Spain). Marine Ecology Progress Series.

Bricker, S. B., Ferreira, J. G., Simas, T., 2003. An in tegrated methodology for assessment of estuarine trophic status. Ecological Modelling 169, 39-60.

Bustos-Baez, S., Frid, C., 2003. Using indicator species to assess the state of macrobenthic communities. Hydrobiologia 496, 299-309.

Carlberg, S.R., 2005. Conservation of marine ecological quality - a current European perspective. Aquatic Conservation Marine Freshwater Ecosystem 15, 211-214.

Dale, V. H., Beyeler, S.C., 2001. Challenges in the development and use of ecological indicators. Ecological Indicators 1, 3-10.

Dauer, D.M., Luckenbach, M.W., Rodi, A.J., 1993. Abundance-biomass comparison ABC method: effects of an estuarine gradient, anoxic/hypoxic events and contaminated sediments. Marine Biology 116, 507-518. 
Dauer, D.M, Ranasinghe. J.A., Weisberg, S. B., 2000. Relationships between benthic community condition, water quality, sediment quality, nutrient loads, and land use patterns in Cheasapeake Bay. Estuaries 23, 80-96.

Dauer, D.M., Lane, M.F., Llanso, R. J., 2002. Development of diagnostic approaches to determine sources of anthropogenic stress affecting benthic community condition in the Chesapeake Bay. Final Report, US EPA Cheseapake Bay Program office, 65 p.

Dauer, D.M., Llanso, R.J., 2003. Spatial scales and probability based sampling in determining levels of benthic community degradation in the Chesapeake Bay. Environmental Monitoring and Assessment 81, 175-186.

Dauvin, J.C., 1993. Le benthos : témoin des variations de l'environnement. Océanis 19, 2553.

Dauvin, J.C., Gomez Gesteira, J.L., Gentil, F., Ghertsos, K., Ropert, M., Sylvand, B., Thiébaut, E., 2004. Spatial structure of a subtidal macrobenthic community in the Bay of Veys (western Bay of Seine, English Channel). Journal of Experimental Marine Biology and Ecology 307, 217-235.

Dauvin, J.C., Desroy, N., 2005. The food web in the lower part of the Seine estuary: a synthesis synopsis of existing knowledge. Hydrobiologia 540, 13-27.

Dauvin, J.C., Desroy, N., Jan son, A.L., Vallet, C., Duhamel, S., 2006. Recent changes in estuarine benthic and suprabenthic communities resulting from the development of harbour infrastructure. Marine Pollution Bulletin 53, 80-90.

Dauvin, J.C., Ruellet, T. (submitted). Polychaete/Amphipod ratio revisited. Marine Pollution Bulletin .

Dauvin, J.C. (in press). Effects of heavy metal contamination on the macrobenthic fauna in estuaries: the case of the Seine estuary. Hydrobiologia.

Diaz, R.J., Solan, M., Valente, R.M., 2003. A review of approaches for classifying benthic habitats and evaluating habitat quality. Journal of Environmental Management 73, 165181.

Donath-Hernadez, F.E., Loya-Salinas, D.H., 1989. Contribucion al estudio de la contaminacion organica marina de la Bahia de Todos Santos, Baja California. Contribution to the study of organic marine pollution in Bahia de Todos Santos, Baja California. Ciencas Marinas 15, 73-88.

Eaton, L., 2001. Development and validation of biocriteria using benthic macroinvertebrates for North Carolina estuarine waters. Marine Pollution Bulletin 42, 23-30. 
Eleftheriou, A., Holme, N.A., 1984. Macrofauna techniques. In: Holme N.A., McIntyre, A.D. (Eds), Methods for the study of marine benthos. Oxford: Blackwell Scientific Publications, pp. 140-216.

Fulton, E.A., Smith, A.D.M., Punt, A.E., 2005. Which ecological indicators can robustly detect effects of fishing? ICES Journal of Marine Science 62, 540-551.

Gentil, F., Cabioch, L., 1997. Carte des peuplements macroben thiques de la Baie de Seine et Manche centrale sud. Carte et notice explicative de la carte. Edition de la Station Biologique de Roscoff.

Ghertsos, K., 2002. Structure spatio-temporelle des peuplements macrobenthiques de la baie de Seine à plusieurs échelles d'observation. Thèse de l'Université des Sciences et Technologies de Lille, $182 \mathrm{p}$.

Grall, J., Glémarec, M., 1997. Using biotic indices to estimate macrobenthic community perturbations in the Bay of Brest. Estuarine, Coastal and Shelf Science 44, 43-53.

Grall, J., Glémarec, M., 2003. L'indice d'évaluation de l'endofaune côtière. In: Bioévaluation de la qualité environnementale des sédiments portuaires et des zones d'immersion, Alzieu, C. (coord.). Éd. Ifremer, 51-85.

Gomez Gesteira, L., Dauvin, J.C., 2000. Amphipods are good bioindicators of the impact of oil spills on soft-bottom macrobenthic communities. Marine Pollution Bulletin 40, 10171027.

Labrune, C., Amouroux, J.M., Sarda, R., Dutrieux, E., Thorin, S., Rosenberg, R., Grémare, A., 2006. Characterization of the ecological quality of the coastal Gulf of Lions (NW Mediterranean). A comparative approach based on three biotic indices. Marine Pollution Bulletin 52, 34-47.

Lafite, R., Romana, A., 2001. A man-altered macrotidal estuary: the Seine estuary (France): introduction to the special issue. Estuaries 24, 939.

Lesourd, S., Lesueur, P., Brun-Cottan, J.C., Auffret, J.P., Poupinet, N., Laignel B., 2001. Morphosedimentary evolution of the macrotidal Seine estuary subjected to human impact. Estuaries 24, 940-949.

Link, J.S., 2005. Translating ecosystem indicators in to decision criteria. ICES Journal of Marine Science 62, 569-576.

Llanso R.J,. Dauer, D.M., 2002. Methods for calculating the Chesapeake Bay Benthic Index of Biotic Integrity. Final Report, Chesapeake Bay Benth ic Monitoring Program, 24p. 
Llanso, R.J., Scott, L.C., Dauer, D. M., Hyland, J.L,. Russell, D.E., 2002a. An estuarine benthic index of biotic integrity for the Mid-Atlantic Region of the United States. I. Classification of assemblages and habitat definition. Estuaries 25, 1219-1230.

Llanso, R.J., Scott, L.C., Hyland, J.L., Dauer, D.M., Russell, D.E., Kutz, F.W., 2002b. An estuarine benthic index of biotic integrity for the Mid-Atlantic Region of the United States. II. Index development. Estuaries 25, 1231-1242.

Marin-Guirao, L., Cesar, A., Marin, A., Lloret, J., Vita, R., 2005. Establishing the ecological quality status of soft-bottom mining-impacted coastal water bodies in the scope of the Water Framework Directive. Marine Pollution Bulletin 50, 374-387.

Maurer, D., Nguyen, H., Robertson, G., Gerlinger, T., 1999. The infaunal trophic index (ITI) : its suitability for marine environmental monitoring. Ecological Application 9, 699-713.

Mearns, A.J., Word, J.Q., 1982. Forecasting effects of sewage solids on marine benthic communities. In: Mayer, G.F. (Ed), Ecological stress and the New York Bight: science and management. Columbia, Estuarine Research Federation, pp. 495-512.

Miramand, P., Guyot T., Rybarczyk, H., Mouny, P., Dauvin, J.C., Bessineton, C., 2001. Contamination of the biological compartment in the Seine estuary by $\mathrm{Cd}, \mathrm{Cu}, \mathrm{Pb}$ and $\mathrm{Zn}$. Estuaries 24, 1056-1065.

Mouny, P., Dauvin, J.C., Bessineton, C., Elkaïm, B., Simon, S., 1998. Biological components from the Seine estuary: first results. Hydrobiologia 373/374, 333-347.

Muniz, P., Venturini, N., Pires-Vanin, A.M.S., Tommasi, L.R., Borja, A. (2005). Testing the applicability of a Marine Biotic Index (AMBI) to assessing the ecological quality of softbottom benthic communities, in the South America Atlantic region. Marine Pollution Bulletin 50, 624-637.

Muxika, I. Borja A., Bonne, W., 2005. The suitability of the marine biotic index (AMBI) to new impact sources along European coasts. Ecological Indicators 5, 19-31.

Occhipinti Ambrogi, A., Forni, G., 2004. Biotic indices. Biologia Marina Mediterranea 11, 545-572.

Pearson T.H., Rosenberg R., 1978. Macrobenthic succession in relation to organic enrichment and pollution of the marine environment. Oceanography and Marine Biology: an Annual Review 16, 229-311.

Reiss H., Kröncke, I., 2005. Seasonal variability of benthic indices: an approach to test the applicability of different indices for ecosystem quality assessment. Marine Pollution Bulletin 50, 1490-1499. 
Rice, J.C., Rochet, M.J, 2005. A framework for selecting a suite of indicators for the fisheries management. ICES Journal of Marine Science 62, 516-527.

Rogers, S. I. Greenaway, B., 2005. A UK perspective of the development of marine ecosystem indicators. Marine Pollution Bulletin 50, 9-19.

Rosenberg, R., Blomqvist, M., Nilsson, H.C. Cederwall, H., Dimming A., 2004. Marine quality assessment by use of benthic species-abundance distributions: a proposed new protocol within the European Union Water Framework Directive. Marine Pollution Bulletin 49, 728-739.

Salas, F., Neto, J.M., Borja, A., Marques, J.C., 2004. Evaluation of the applicability of a marine biotic index to characterize the status of estuarine ecosystems: the case of Mondego estuary (Portugal). Ecological Indicators 4, 215-225.

Scherrer, B., 1984. Biostatistique. Gaëtan Morin éditeur, Chicoutimi, Québec, Canada, 850 p.

SGSOBS (Study Group on Ecological Quality Objectives for Sensitive and for Opportunistic Benthos Species), 2004. Report of the Study Group on ecological quality objectives for Sensitive and for Opportunistic Benthos Species. Conseil International pour l'Exploration de la Mer, 37p.

Simboura, N., Zenetos, A., 2002. Benthic indicators to use in Ecological Quality classification of Mediterranean soft bottom marine ecosystems, including a new Biotic Index. Mediterranean Marine Science 3, 77-111.

Simboura, N., 2004. Bentix index vs Biotic Index in monitoring: an answer to Borja et al., 2003. Marine Pollution Bulletin 48, 403-404.

Thiébaut, E., Cabioch, L., Dauvin, J.C., Retière, C., Gentil, F., 1997. Spatio-temporal persistence of the Abra alba-Pectinaria koreni muddy-fine sand community of the eastern Bay of Seine. Journal of the Marine Biological Association of the United Kingdom 77, 1165-1185.

Tronzynski, J. (coord.), 1999. Les contaminants organiques qui laissent des traces : sources, transport et devenir. Editions de l'IFREMER, Programme Scientifique Seine Aval, fascicule $12,39 \mathrm{p}$.

Vincent, C., Hein rich, H., Edwards, A., Nygaard, K., Haythornthwarite, J., 2002. Guidance on typology, reference conditions and classification sys tems for transitional and costal waters, CIS Working Group 2.4 (Coast) Common Implementation Strategy of the Water Framework Directive, European Commission. 
Weisberg, S.B., Ranasinghe, J.A., Dauer, D.M., Schaffner, L.C., Diaz, R.J., Frithsen, J.B., 1997. An estuary benthic index of biotic integrity (B-IBI) for Chesapeake Bay. Estuaries 20, 146-158.

Word, J.Q., 1978. The infaunal trophic index. Southern California Coastal Water Research Project, Annual Report 1978, 19-39. 


\section{Legends of the figures and tables}

Figure 1 - Map showing the benthic sites sampled before (March 1996, March 1997 and May 1999) and after (October 1997 and September 1998) the recruitment in the Bay of Seine as well as the limits of the main benthic communities defined by Gentil and Cabioch (1997). The bold dashed line represents the limit between sites located outside (to the west) and inside (to the east) the zone influenced by the Seine River. Coordinates are expressed in decimal degrees.

Figure 2 - Map showing the benthic sites in the eastern part of the Bay of Seine-sampled in February 1998, March 1991 and March 1996-and the limits of the main benthic communities defined by Gentil and Cabioch (1997). Coordinates are expressed in decimal degrees.

Figure 3 - Map showing the benthic sites of the Seine estuary (sampled in November 1993, May and October 1995, February 2001, March, May and September 2002 and from March to December 2002) and the limits of the main benthic communities defined by Gentil and Cabioch (1997). Coordinates are expressed in decimal degrees.

Figure 4 - AMBI and BQI values in the Bay of Seine before and after the recruitment period. Dashed lines represent the limits of the area studied. Coordinates are expressed in decimal degrees.

Figure 5 - Inter-annual evolution of AMBI and BQI values in the Eastern part of the Bay of Seine: February 1988, March 1991 and March 1996. Dashed lines represent the limits of the area studied. Coordinates are expressed in decimal degrees.

Figure 6-Seasonal evolution of AMBI and BQI values in the Seine estuary: March, May and September 2002. Dashed lines represent the limits of the area studied. Coordinates are expressed in decimal degrees.

Figure 7 - Range of variations observed in the data set used to calculate the 12 indices for the Bay of Seine before (a) and after (b) the benthic recruitment period, for the eastern part of the Bay of Seine in February 1988 (c), March 1991 (d) and March 1996 (e), and for the Seine estuary in 1993 and 1995 (f), in March (g), May (h) and September 2002 (i). The variations in the data set used to study the effect of the mesh size $1 \mathrm{~mm}$ (j) vs $2 \mathrm{~mm}(\mathrm{k})$ in February 2001 are also shown (Black: $2 \mathrm{~mm}$; grey: $1 \mathrm{~mm}$ ). Minimum, median and maximum values are indicated. See text and Table 2 for the meaning of the abbreviations.

Figure 8 - Relationships between sediment parameters, biotic indices, and macrobenthic abundance and diversity indices. Absolutes values of Spearman's rank correlation coefficients are represented on a circle whose centre is 0 and whose range is 1 . Probability (p) of the coefficients and number of data (n) are also indicated. See text for the meaning of the abbreviations.

Figure 9 - Relative frequency of the AMBI and BQI values inside and outside the Seine estuary ( see limits in Fig. 1).

Figure 10 - Comparison of community status for 11 sites, based on the sampling done with a $1 \mathrm{~mm}$ mesh and a $2 \mathrm{~mm}$ mesh in February 2001. 
Table 1. Main characteristics of the subtidal sampling sites in the Bay of Seine and the Seine estuary. * Granulometric analyses available; ** organic matter rate and pigment concentrations in the sediment available; *** 10 sampling dates (excepted in one site where March sampling is missing): March (2 surveys), April (2), May (3), June (1), September (1) and December (1).

Table 2. Indices calculated from the macrobenthos database referring to the Bay of Seine and Seine estuary. AMBI: AZTI Marine Biotic Index; BOPA: Benthic Opportun istic Polychaetes Amphipods index; BQI: Benthic Quality Index; EG: Ecological Group (see text); $\mathrm{f}_{\mathrm{A}}$ : amphipods frequency (except Jassa sp.); $\mathrm{f}_{\mathrm{P}}$ : opportunistic polychaetes frequency; I2EC: Coastal Endofaunic Evaluation Index; ITI: Infaunal Trophic Index; TG: Trophic Group (see text). 
Figure 1
Click here to download high resolution image

Figure 1
Click here to download high resolution image

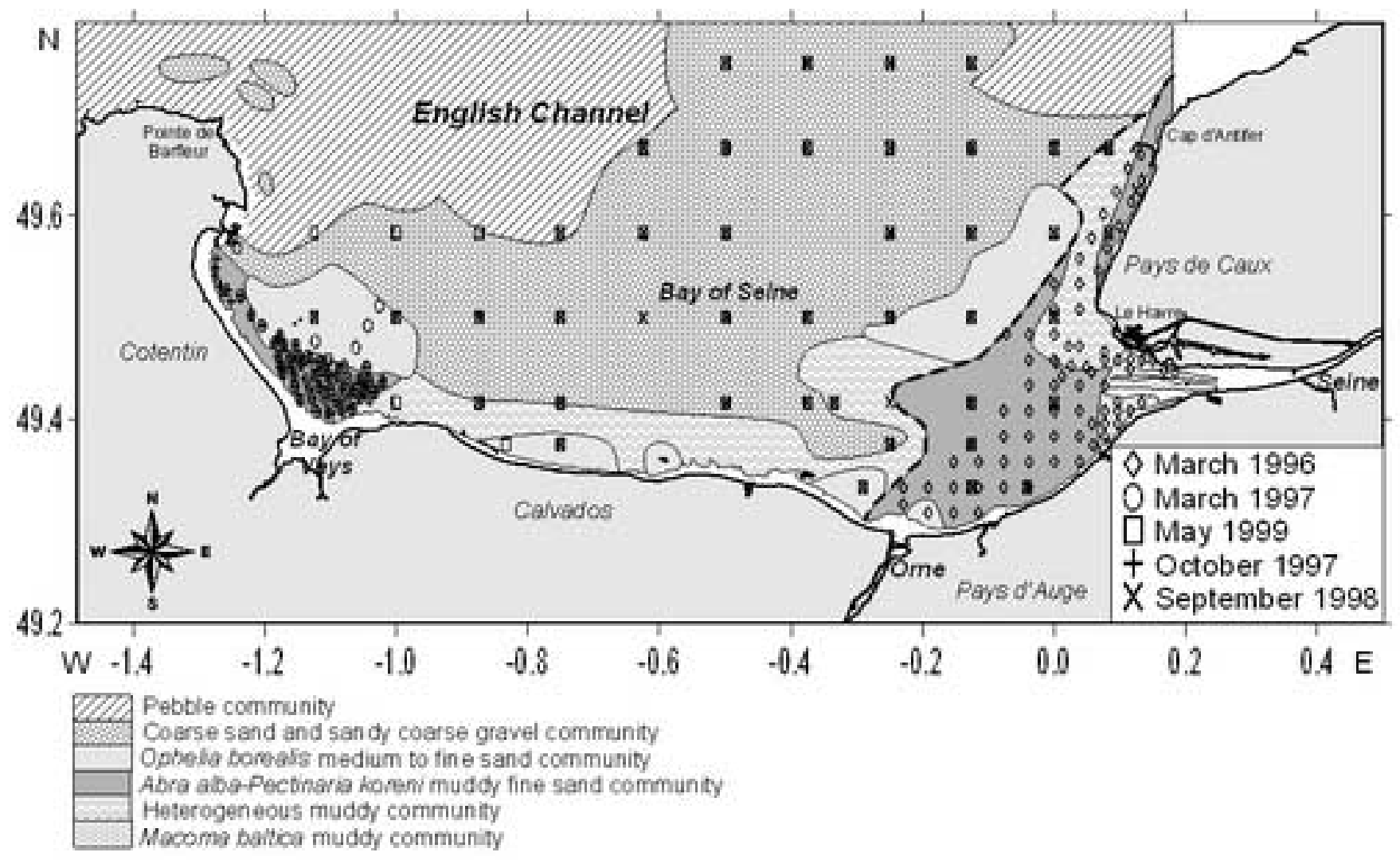

(1)

e

$\left(\frac{10}{2}\right.$

(n)

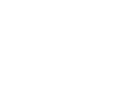
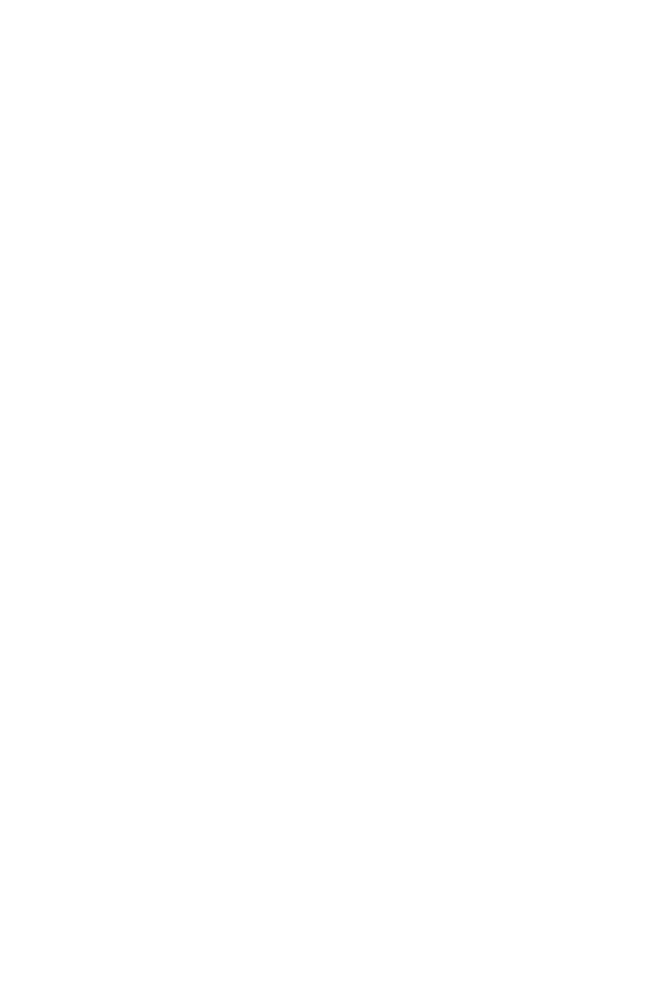
Heterogeneous muddy community
Macoms balica muddy communify 
Figure 2
Click here to download high resolution image

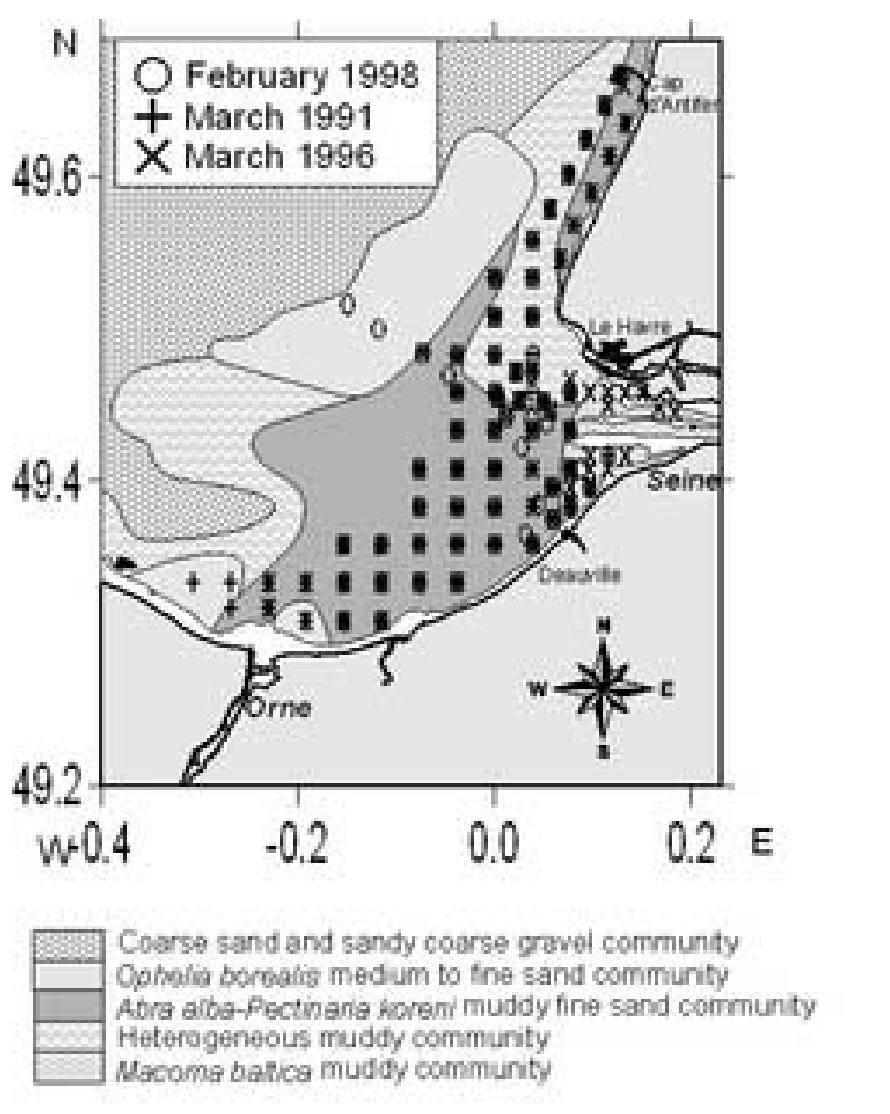

\footnotetext{
Coarse sand and sandy coarse gravel community
Opholia borealis medum to the sand communty
Abra alba-Pectinana horemi muddy fine sand communty
Heterogeneous muddy communty

Coarse sand and sandy coarse gravel community
Opholia borealis medum to the sand communty
Abra alba-Pectinana horemi muddy fine sand communty
Heterogeneous muddy communty

Coarse sand and sandy coarse gravel community
Opholia borealis medum to the sand communty
Abra alba-Pectinana horemi muddy fine sand communty
Heterogeneous muddy communty

Coarse sand and sandy coarse gravel community
Opholia borealis medum to the sand communty
Abra alba-Pectinana horemi muddy fine sand communty
Heterogeneous muddy communty

Nacoma batica muddy communty

recoma basca mudoj communty
}

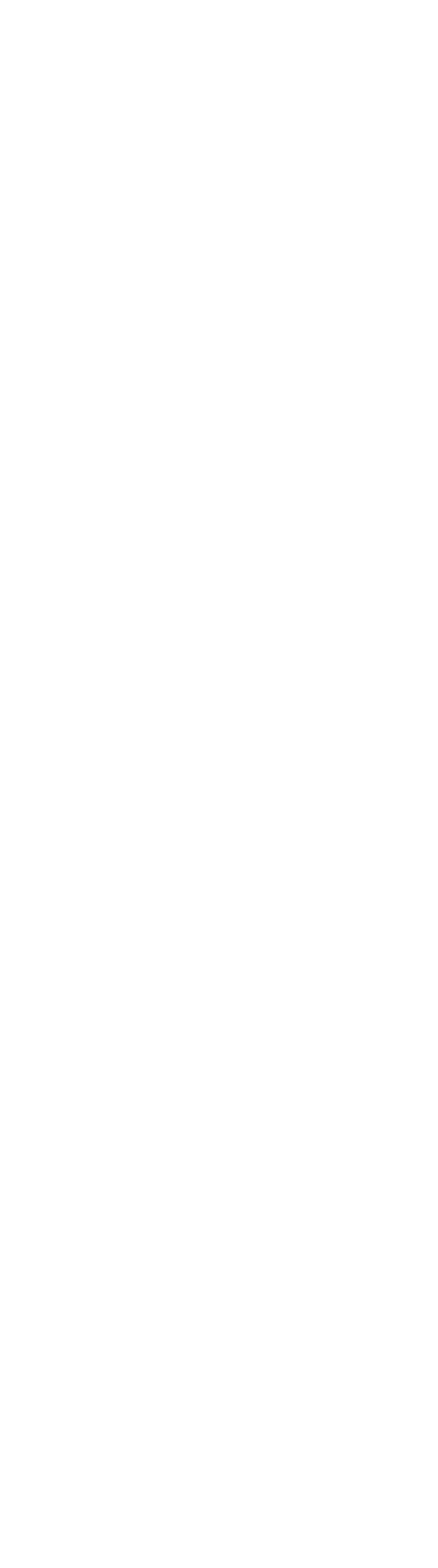




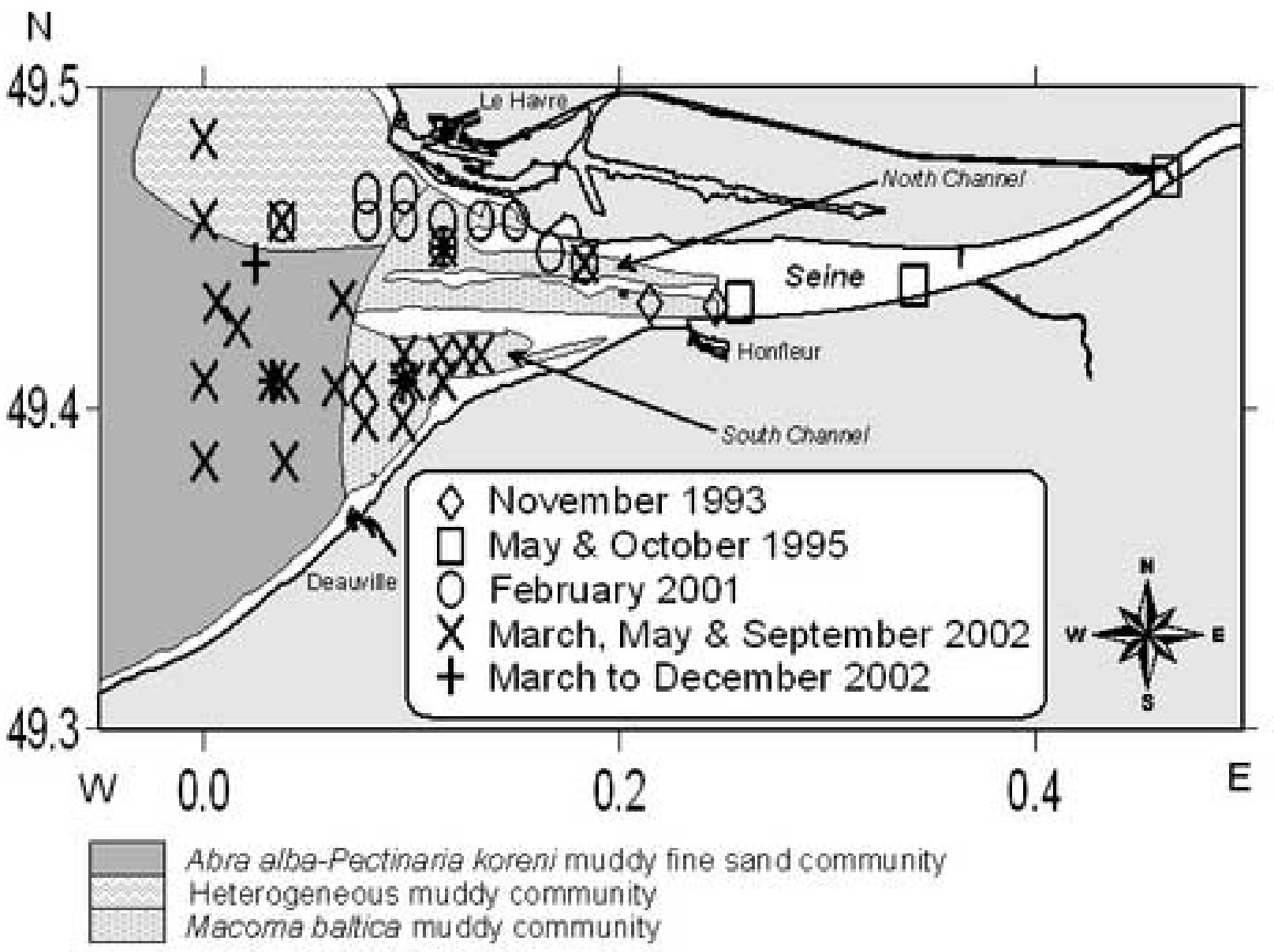


Figure 4
Click here to download high resolution image
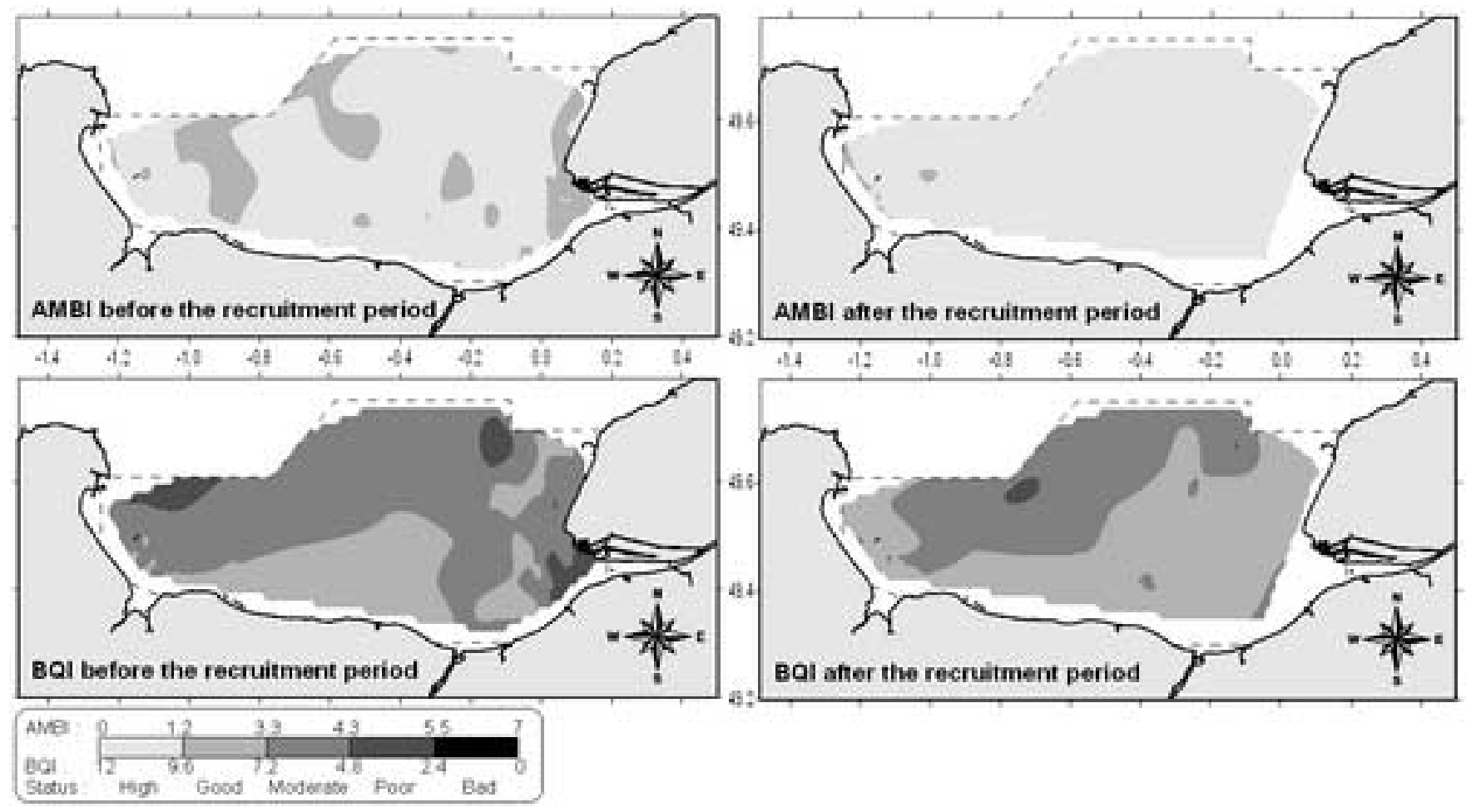

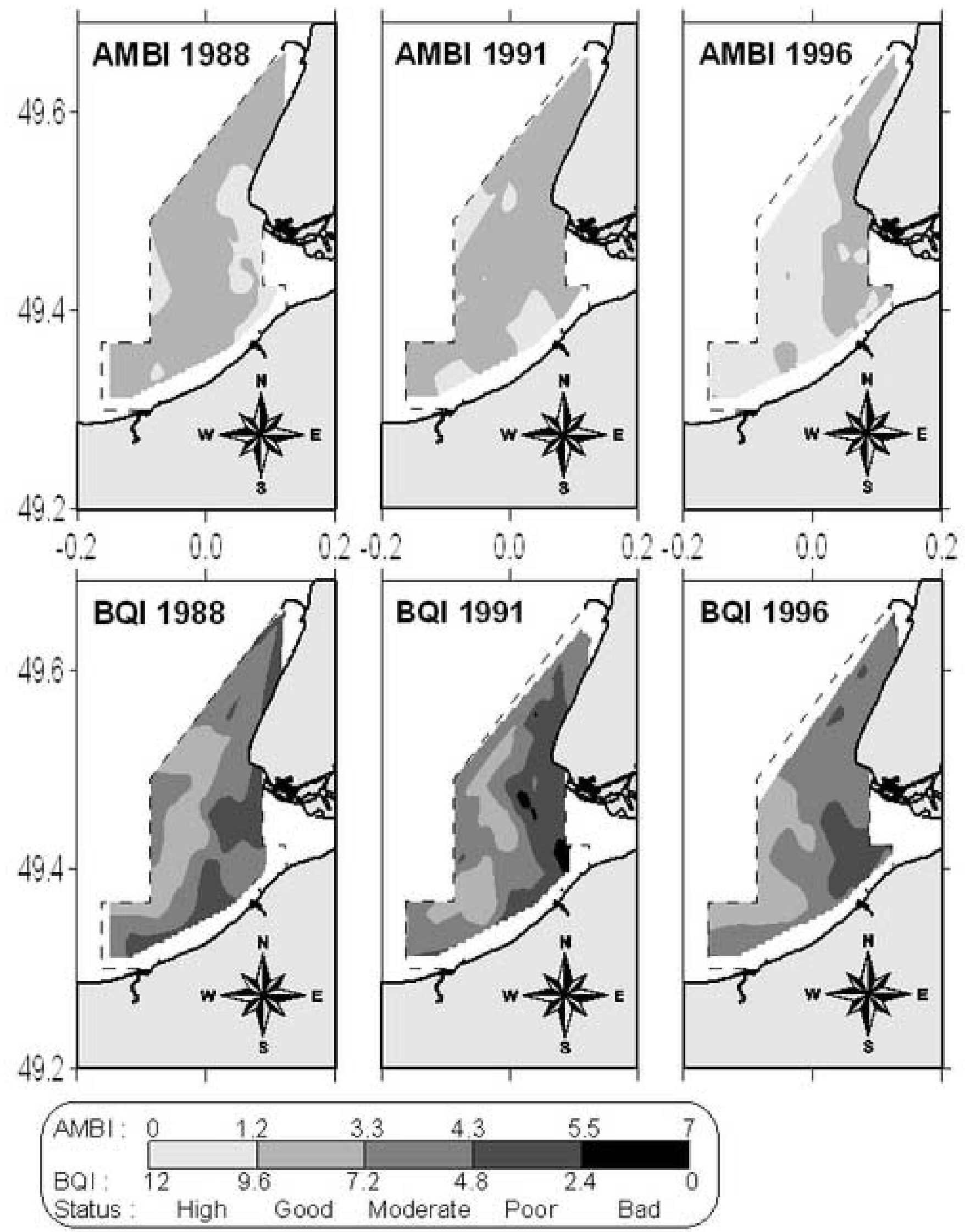

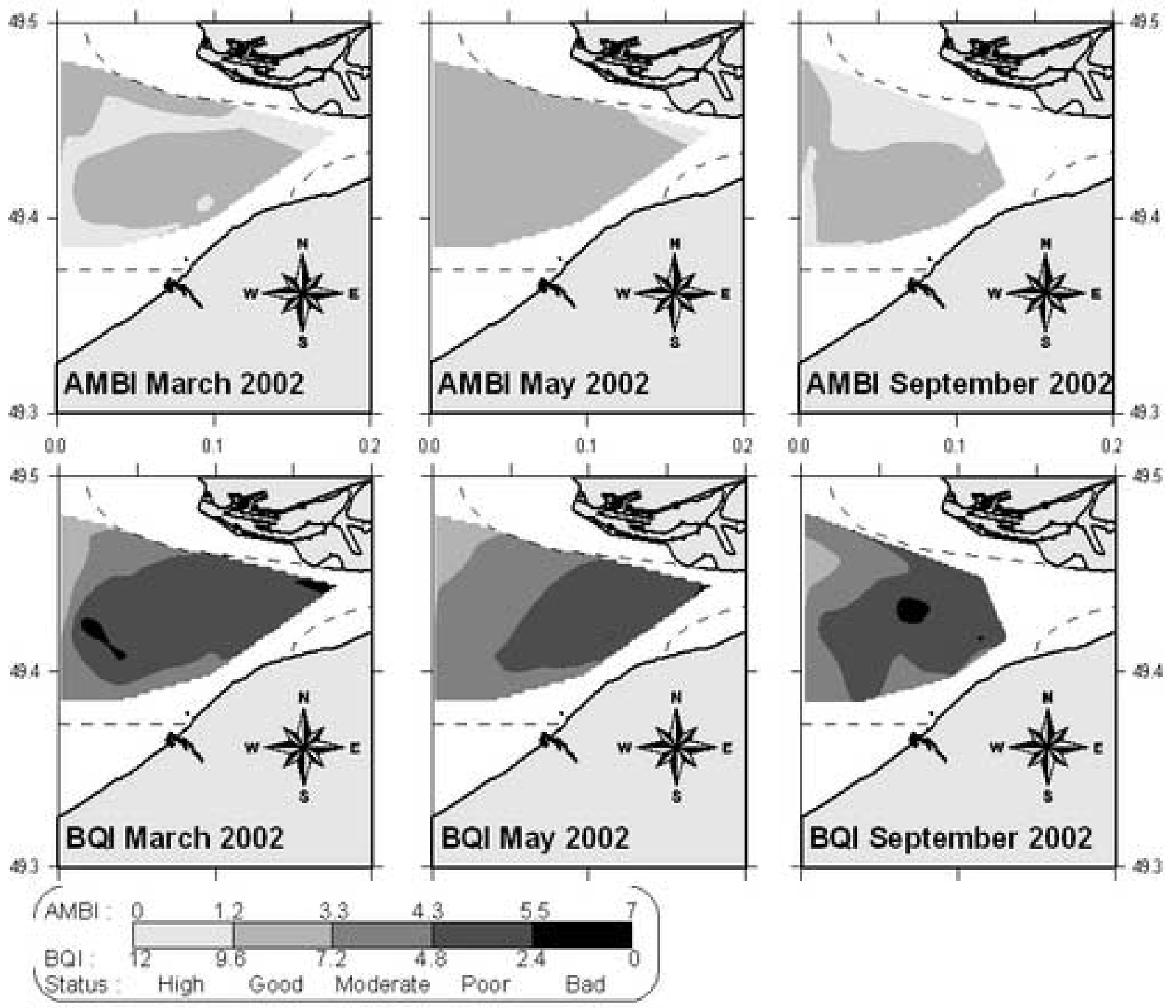


\section{igure 8 \\ Click here to download high resolution image}

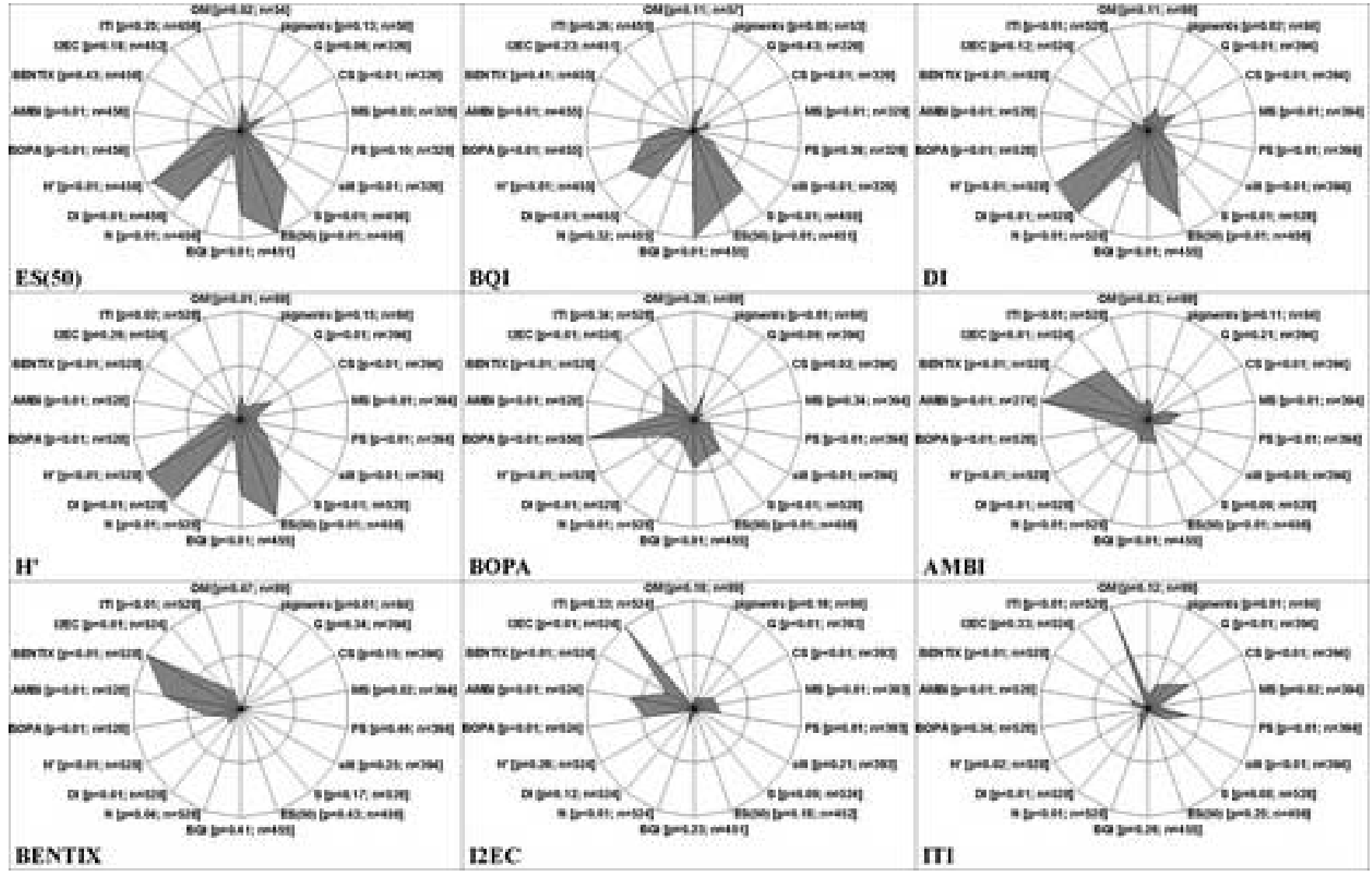


Figure 9

Click here to download high resolution image
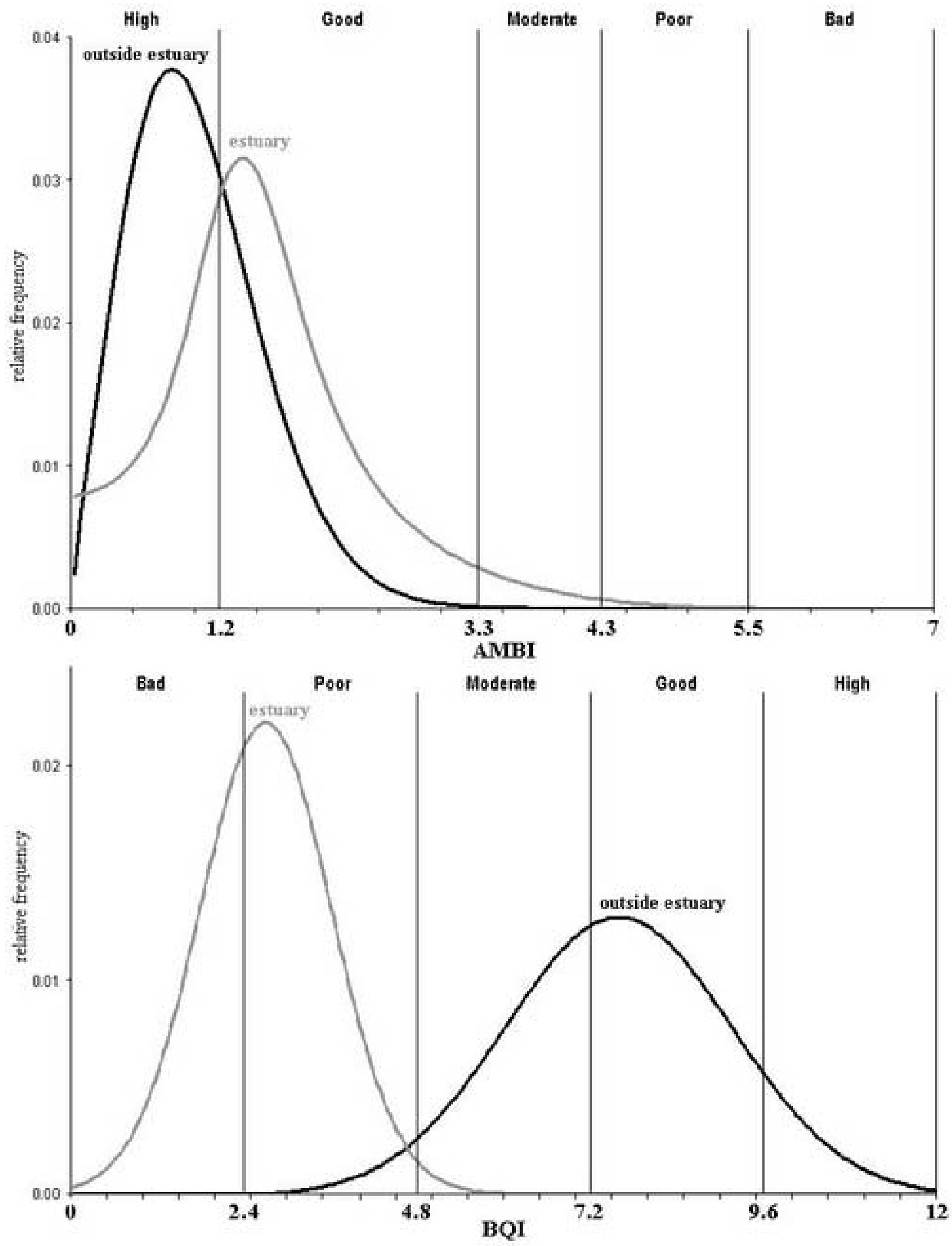
Figure 1
Click here to download high resolution image

Figure 1
Click here to download high resolution image

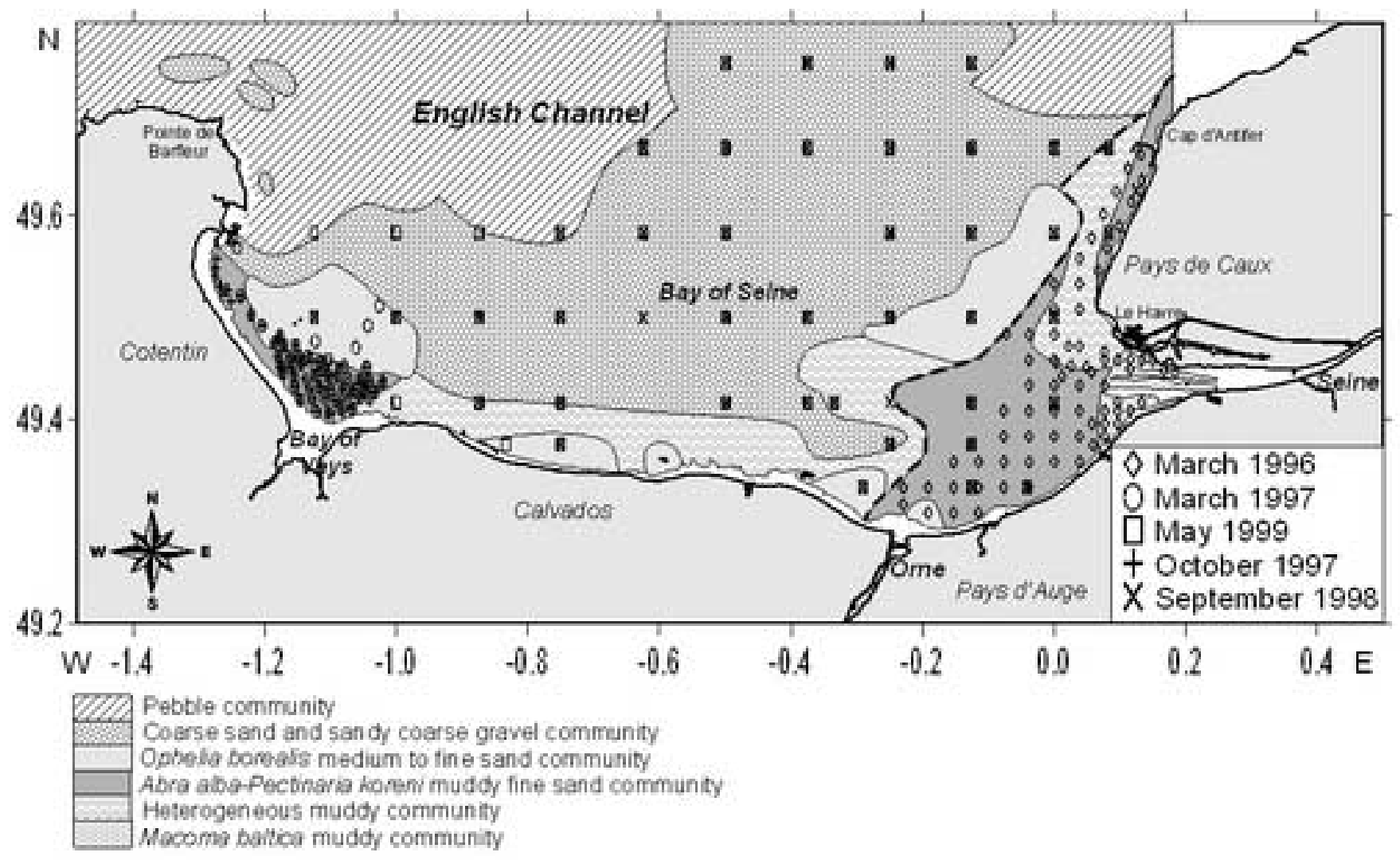

(1)

e

$\left(\frac{10}{2}\right.$

(n)

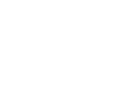
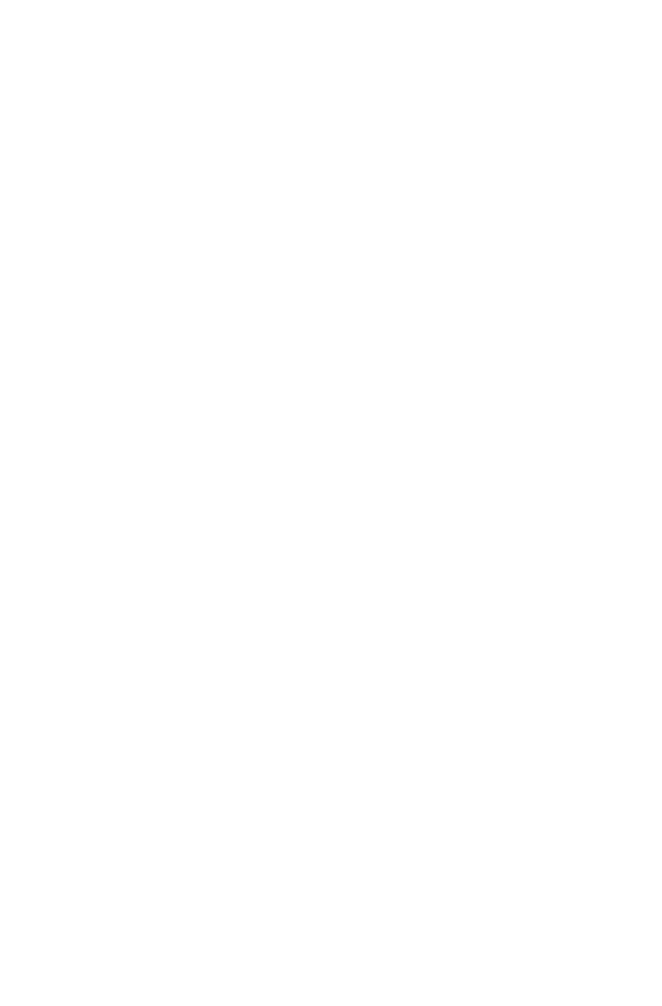
Heterogeneous muddy community
Macoms balica muddy communify 
Figure 2
Click here to download high resolution image

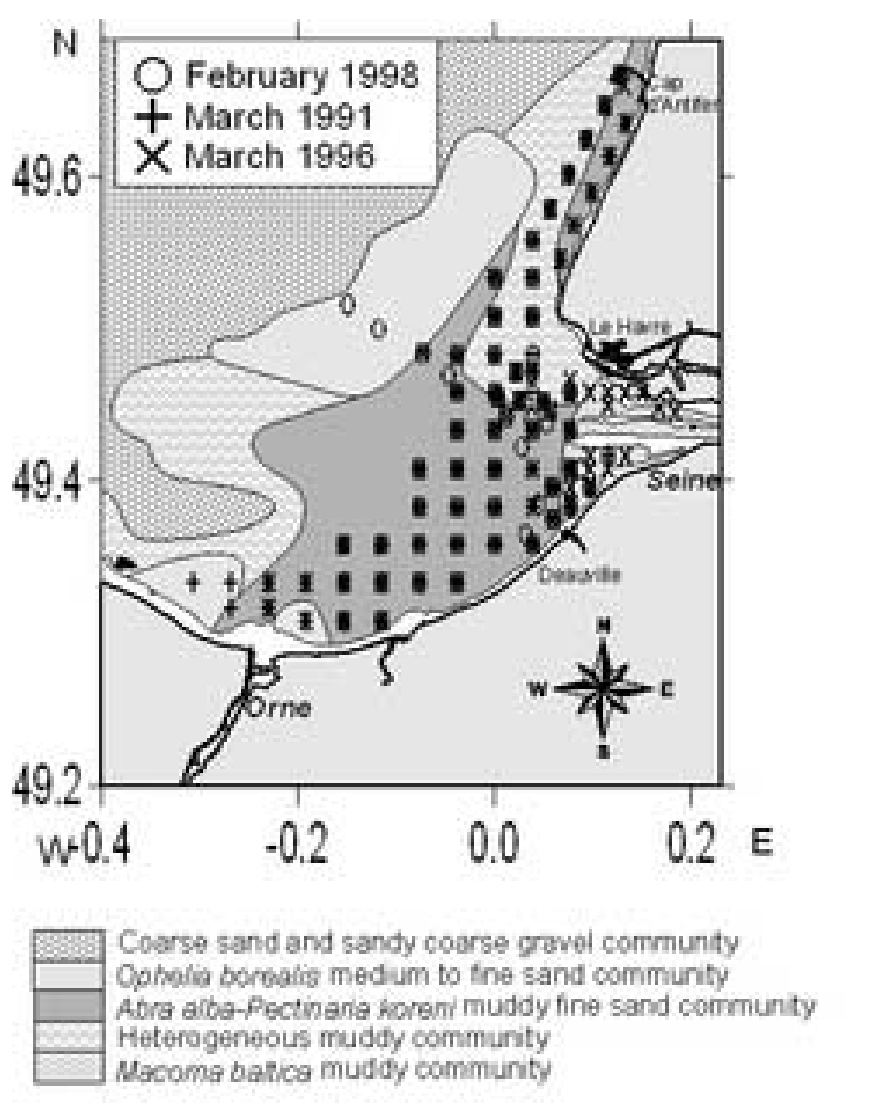

\footnotetext{
Coarse sand and sandy coarse gravel community
Opholia borealis medum to the sand communty
Abra alba-Pectinana horemi muddy fine sand communty
Heterogeneous muddy communty

Coarse sand and sandy coarse gravel community
Opholia borealis medum to the sand communty
Abra alba-Pectinana horemi muddy fine sand communty
Heterogeneous muddy communty

Coarse sand and sandy coarse gravel community
Opholia borealis medum to the sand communty
Abra alba-Pectinana horemi muddy fine sand communty
Heterogeneous muddy communty

Coarse sand and sandy coarse gravel community
Opholia borealis medum to the sand communty
Abra alba-Pectinana horemi muddy fine sand communty
Heterogeneous muddy communty

Nacoma batica muddy communty

recoma basca mudoj communty
}

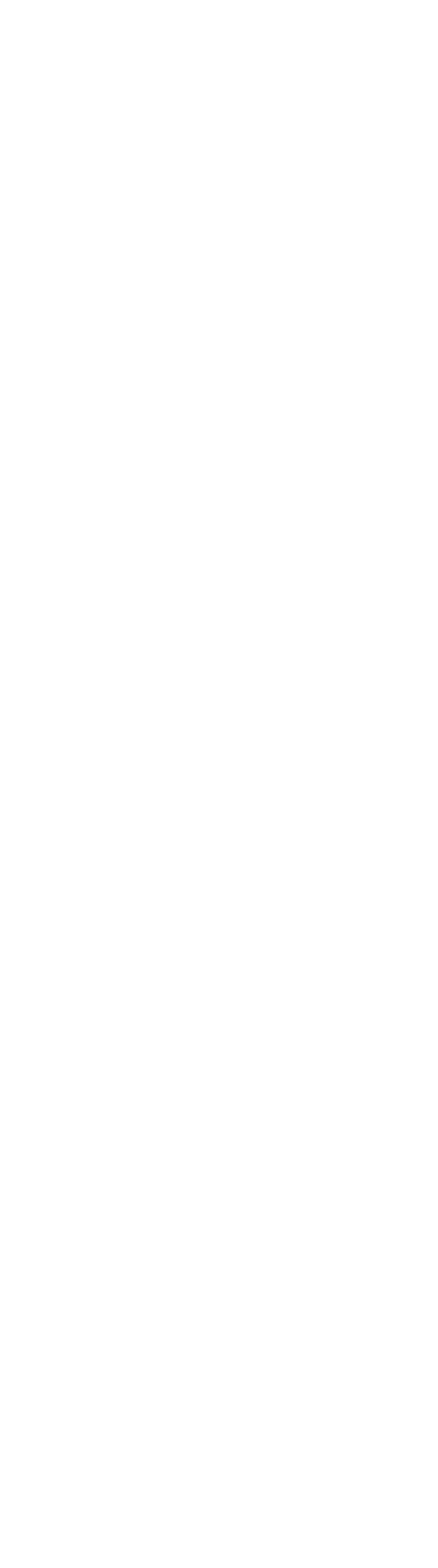




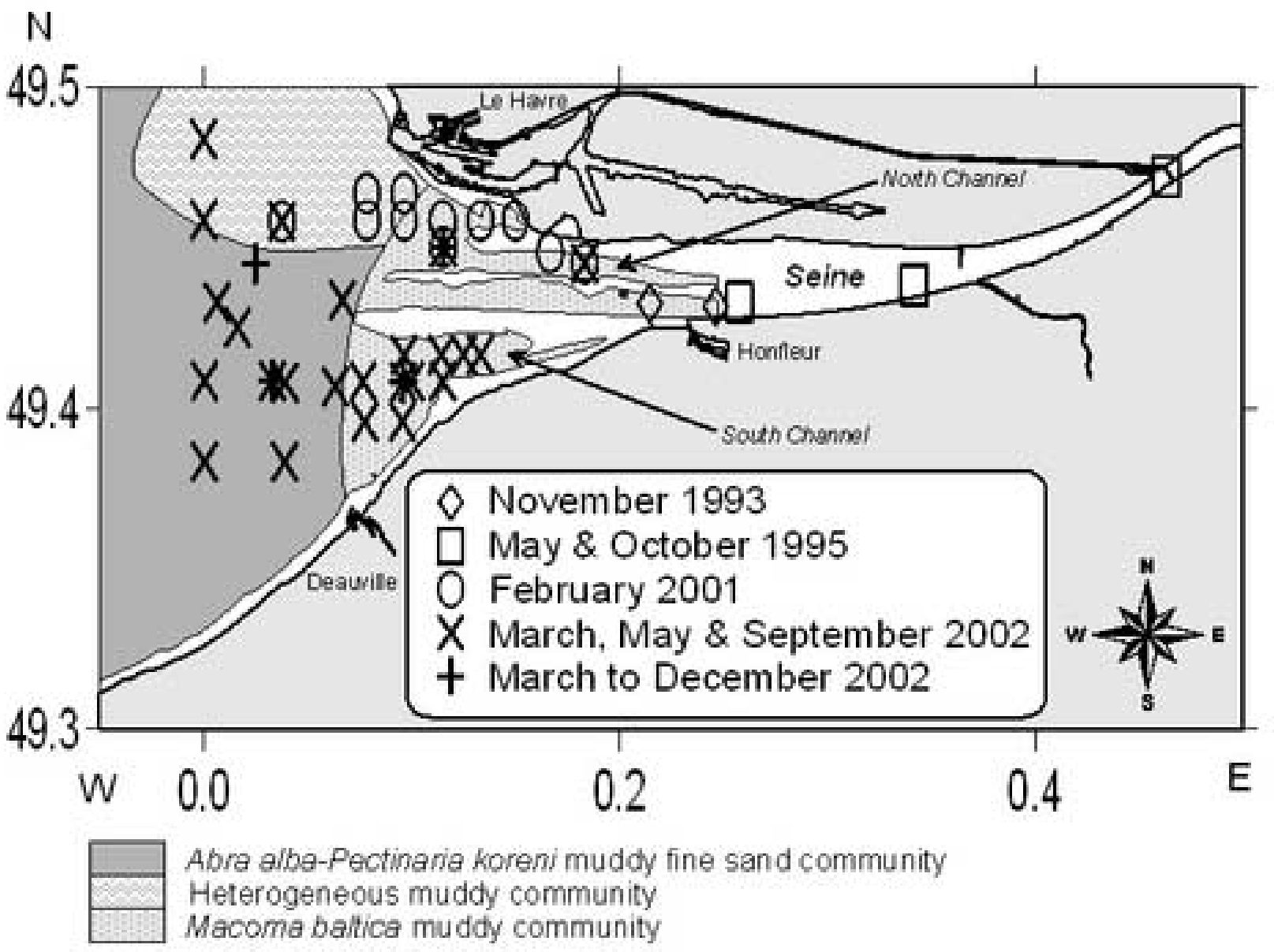


Figure 4
Click here to download high resolution image
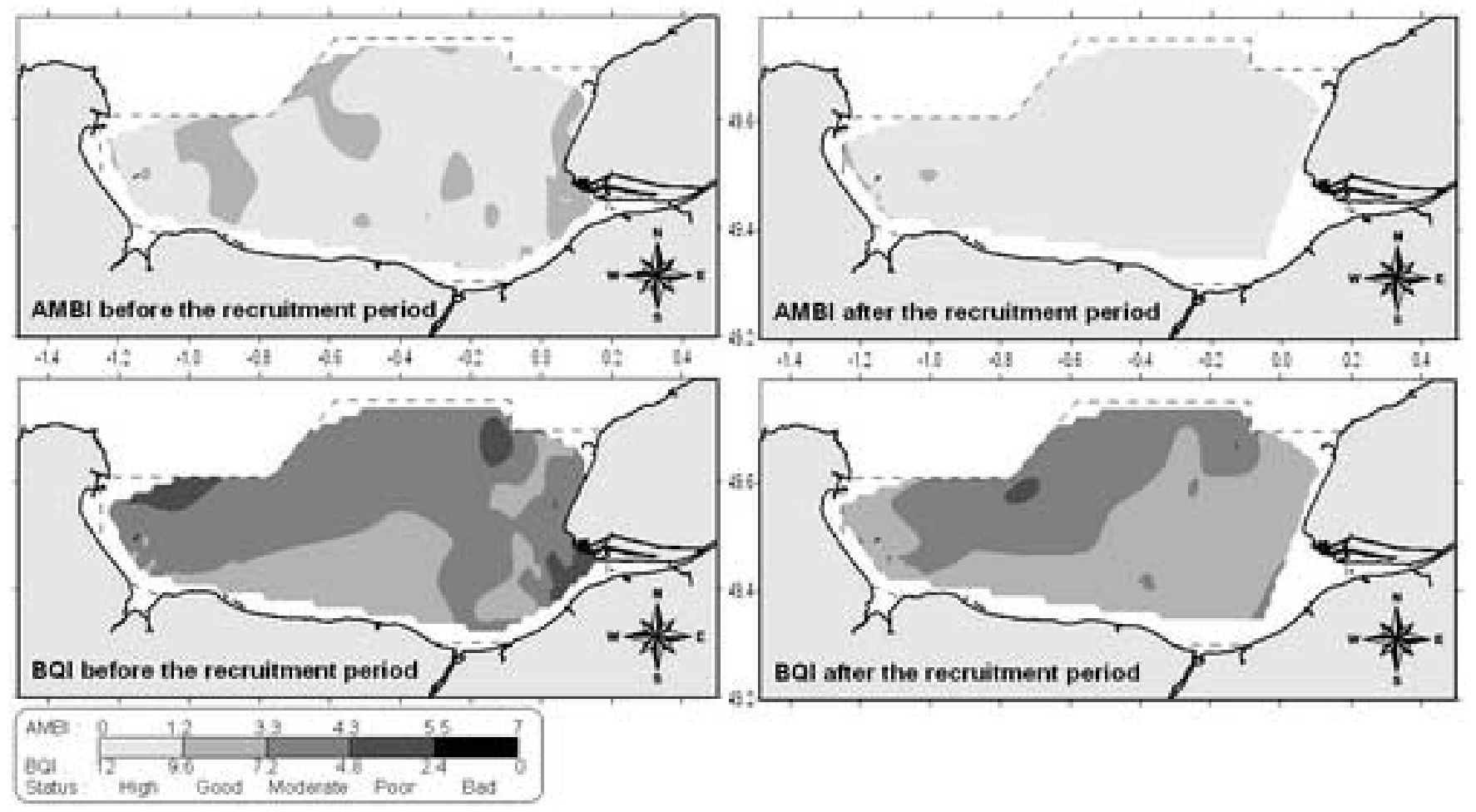

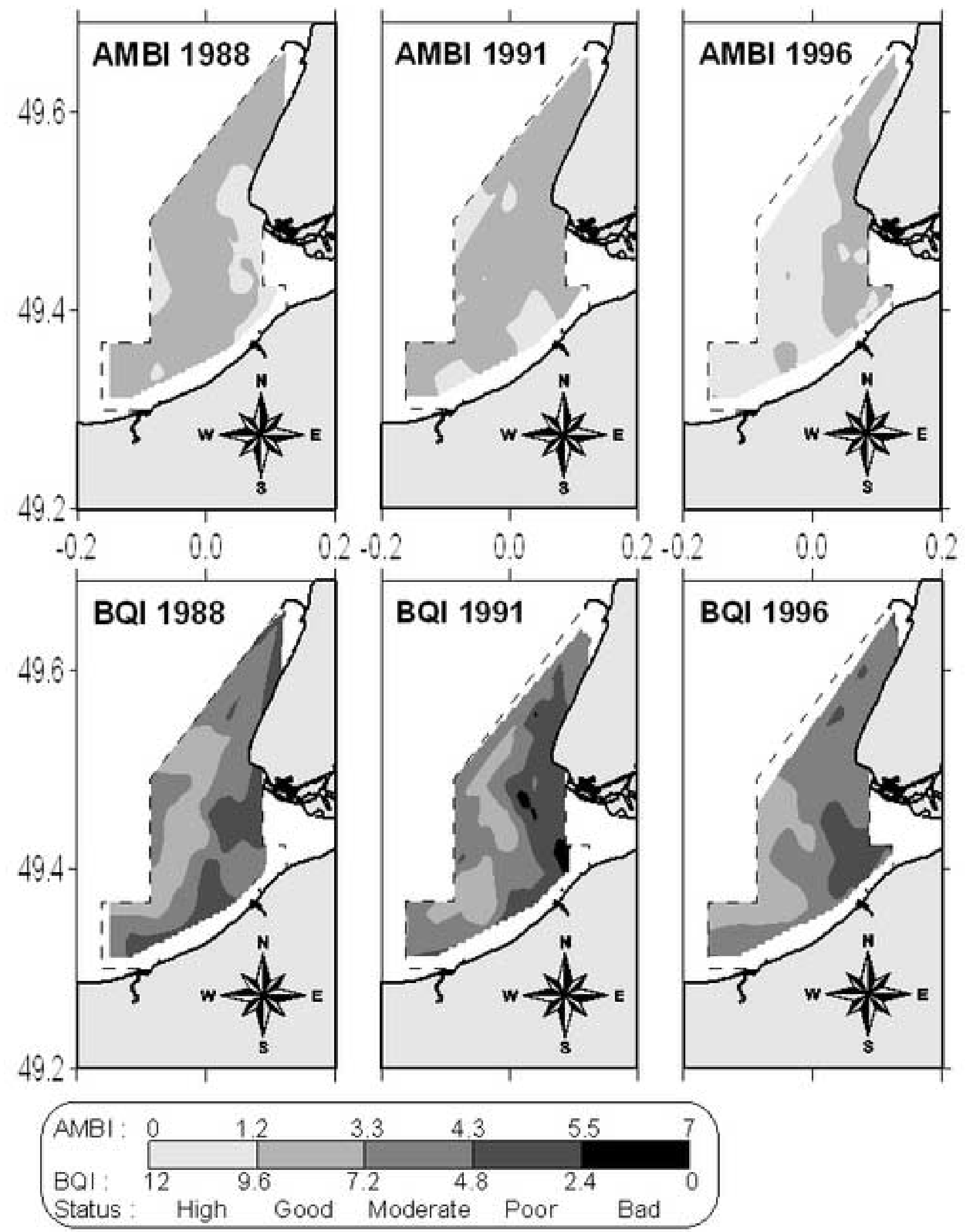

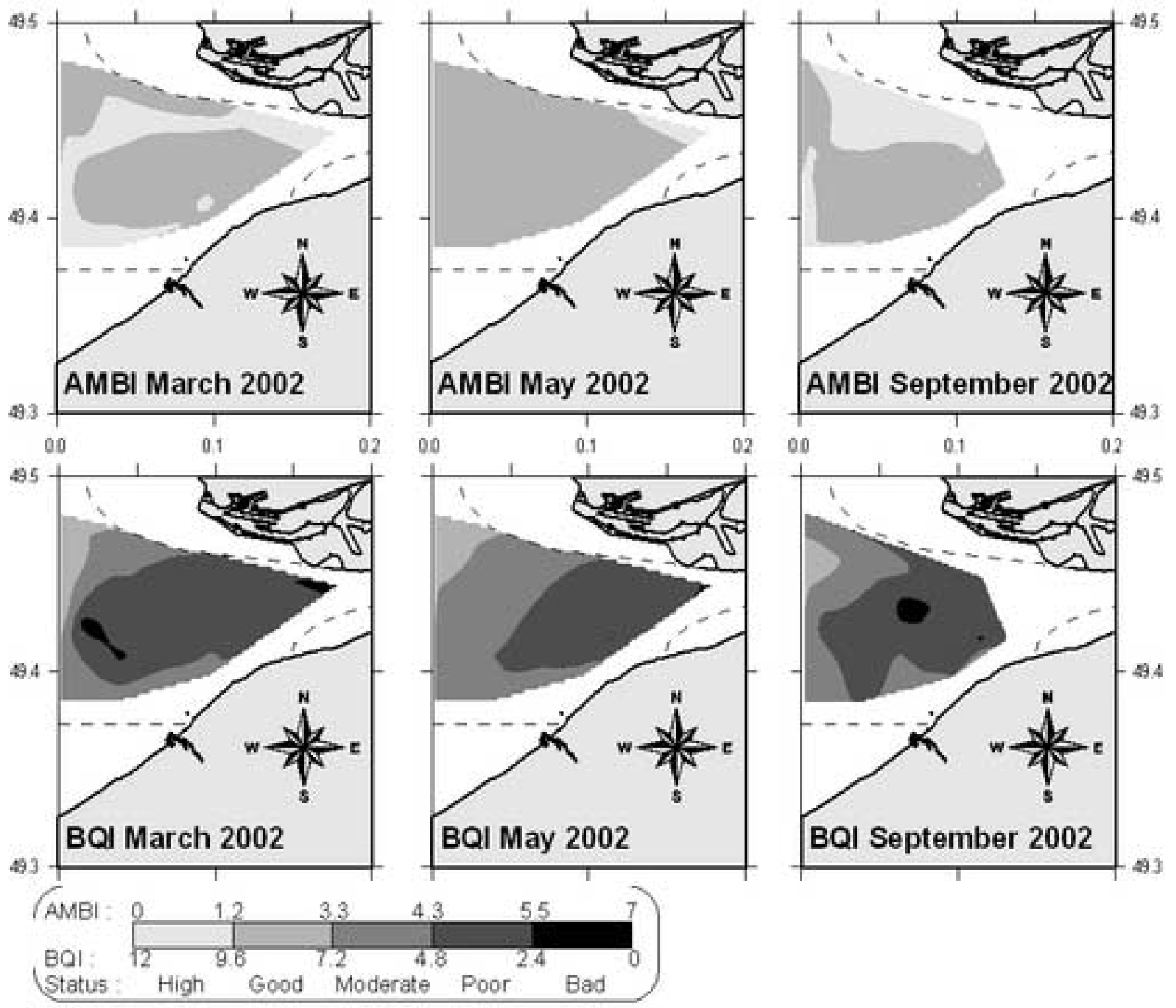


\section{igure 8 \\ Click here to download high resolution image}

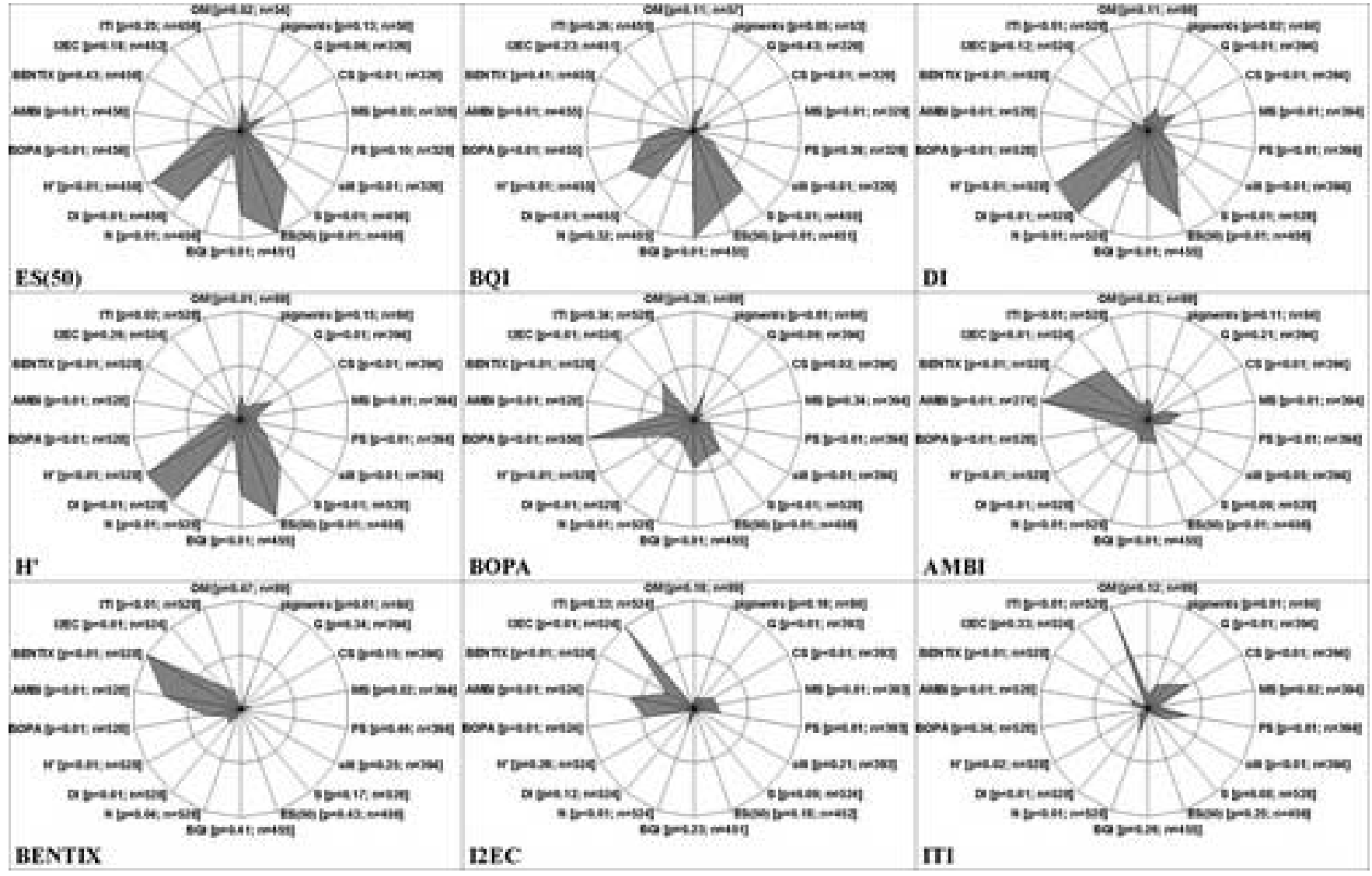


Figure 9

Click here to download high resolution image
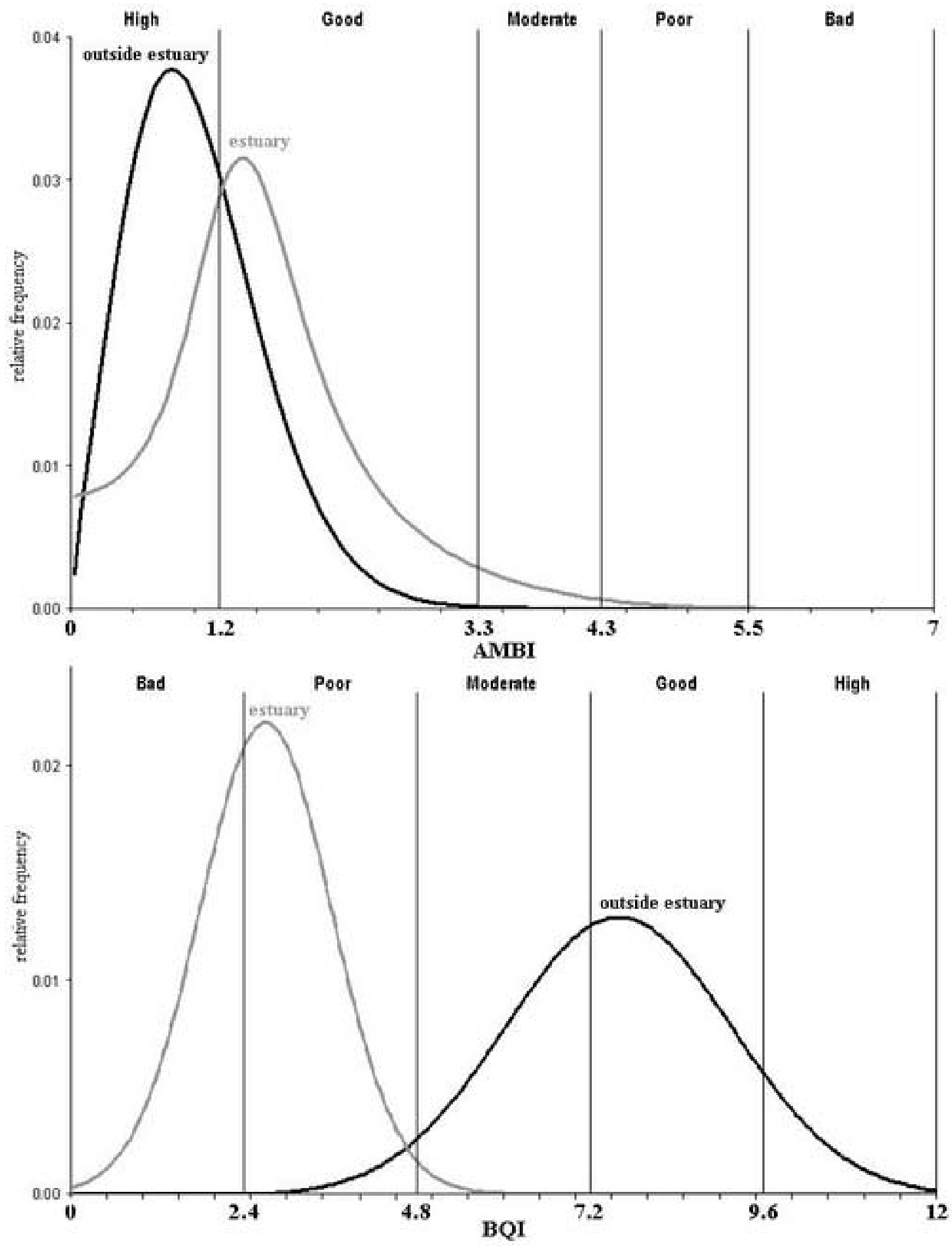
Figure 10

Click here to download high resolution image
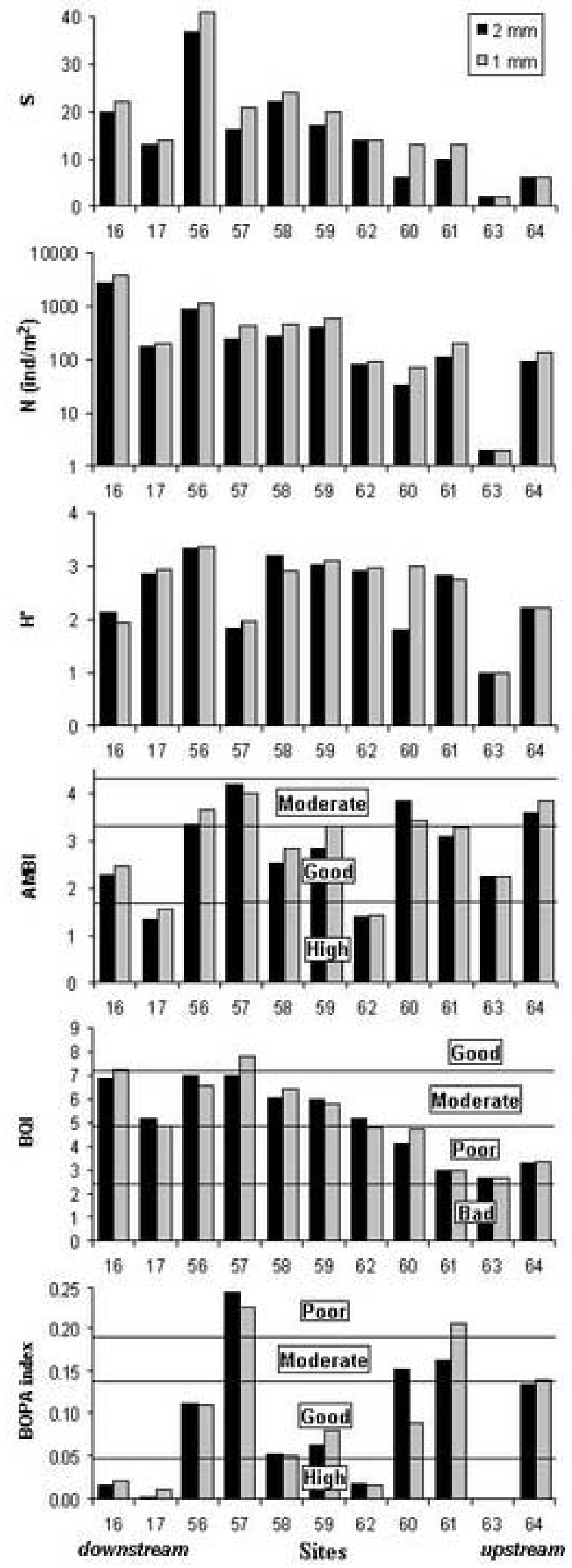


\begin{tabular}{|c|c|c|c|c|c|}
\hline $\begin{array}{l}\text { Sampling zone in } \\
\text { the Bay of Seine }\end{array}$ & Sampling dates & $\begin{array}{c}\text { Number of } \\
\text { sites }\end{array}$ & $\begin{array}{c}\text { Sampling gear and total surface } \\
\text { or volume sampled }\end{array}$ & Sieving mesh & References \\
\hline Eastern part & February 1988 & $64 *$ & Hamon grab $\left(0.5 \mathrm{~m}^{2}\right)$ & $2 \mathrm{~mm}$ & Thiébaut et al., 1997 \\
\hline Eastern part & March 1991 & $64 *$ & Hamon grab $\left(0.5 \mathrm{~m}^{2}\right)$ & $2 \mathrm{~mm}$ & Thiébaut et al., 1997 \\
\hline Bay of Veys & March 1997 & $55^{*}$ & Hamon grab $\left(0.5 \mathrm{~m}^{2}\right)$ & $2 \mathrm{~mm}$ & Dauv in et al., 2004 \\
\hline Bay of Veys & October 1997 & $54 *$ & Hamon grab $\left(0.5 \mathrm{~m}^{2}\right)$ & $2 \mathrm{~mm}$ & Dauvin et al., 2004 \\
\hline Bay of Seine & September 1998 & $44 *, * *$ & Hamon grab $\left(1 \mathrm{~m}^{2}\right)$ & $2 \mathrm{~mm}$ & Ghertsos, 2002 \\
\hline Seine estuary & May and October 1995 & 3 & Rallier du Baty dredge (30 L) & $1 \mathrm{~mm}$ & Mouny et al., 1998 \\
\hline Seine estuary & February 2001 & 11 & Hamon grab $\left(1 \mathrm{~m}^{2}\right)$ & 1 and $2 \mathrm{~mm}$ & Janson \& Desroy, unpublished data \\
\hline Seine estuary & March, May and September 2002 & 23 & Hamon grab $\left(0.5 \mathrm{~m}^{2}\right)$ & $2 \mathrm{~mm}$ & Janson \& Desroy, unpublished data \\
\hline Seine estuary & March to December 2002 & $4 * * *$ & Van Veen grab $\left(0.5 \mathrm{~m}^{2}\right)$ & $1 \mathrm{~mm}$ & Janson \& Desroy, unpublished data \\
\hline
\end{tabular}




\begin{tabular}{|c|c|c|}
\hline Variable & Determination or calculation & References \\
\hline $\mathrm{S}$ & Number of species & - \\
\hline $\mathrm{n}_{\mathrm{i}}$ & Number of individuals belonging to the $i^{\text {th }}$ species & - \\
\hline $\mathrm{N}$ & $\Sigma \mathrm{n}_{\mathrm{i}}$, total number of individuals per $\mathrm{m}^{2}$. & - \\
\hline Dominance & $\sum \mathrm{n}_{\mathrm{i}} \mathrm{x}\left(\mathrm{n}_{\mathrm{i}} /(\mathrm{N}-1)\right)$ & - \\
\hline H (Brillouin) & $\mathrm{N}^{-1} \ln \left(\mathrm{N} ! /\left(\mathrm{N}_{1} ! \mathrm{N}_{2} ! \ldots \mathrm{N}_{\mathrm{s}} !\right)\right)$ & in SGSOBS (2004) \\
\hline $\mathrm{ES}_{(50)}$ & Expected number of species for 50 individuals & Rosenberg et al. (2004) \\
\hline $\mathrm{H}^{\prime}$ (Shannon) & $-\Sigma\left[\left(n_{i} / N\right) \times \log _{2}\left(n_{i} / N\right)\right]$ & in SGSOBS (2004) \\
\hline BQI & $\Sigma\left[\left(\mathrm{n}_{\mathrm{i}} / \Sigma \mathrm{ni}\right) \times \mathrm{ES} 50_{0.05 \mathrm{i}}\right] \times \log _{10}(\mathrm{~S}+1)$ & Rosenberg et al. (2004) \\
\hline AMBI & $0 \mathrm{EG}_{\mathrm{I}}+1.5 \mathrm{EG}_{\mathrm{II}}+3 \mathrm{EG}_{\mathrm{III}}+4.5 \mathrm{EG}_{\mathrm{IV}}+6 \mathrm{EG}_{\mathrm{V}}$ & Borja et al. (2000) \\
\hline BENTIX & $6 \mathrm{EG}_{\mathrm{I} \& \mathrm{II}}+2 \mathrm{EG}_{\mathrm{III}, \mathrm{IV}} \& \mathrm{~V}$ & Simboura and Zenetos (2002) \\
\hline I2EC & Key of determination based on $5 \mathrm{EG}$ & Grall and Glémarec (2003) \\
\hline BOPA & $\log _{10}\left[\left(f_{P} /\left(f_{A}+1\right)\right)+1\right]$ & $\begin{array}{l}\text { Gesteira and Dauvin (2000), revised in } \\
\text { Dauvin and Ruellet (submitted) }\end{array}$ \\
\hline ITI & $100-33.3\left(\mathrm{TG}_{2}+2 \mathrm{TG}_{3}+3 \mathrm{TG}_{4}\right) / \mathrm{TG}_{1,2,3,4}$ & Mearns and Word (1982) \\
\hline
\end{tabular}

